\title{
User design as a double-edged sword: Exploring perceived self-improvement and uncertainty
}

\section{in purchasing utilitarian product}

\begin{abstract}
s
Purpose - This study aims to examine the effects of design sources (user design vs. company design) on customers' perceived value (perceived self-improvement and perceived uncertainty) and consequently purchase intention, as well as the moderating effect of brand strength in the context of utilitarian product purchasing.
\end{abstract}

Design/methodology/approach - Two studies were conducted. Study 1 used a laboratory experiment $(n=160)$ to test the effect of design sources on perceived self-improvement, perceived uncertainty, and purchase intention. Study 2 used an online experiment $(n=312)$ to examine the moderating effect of brand strength.

Findings - The results showed that user design is a double-edged sword for companies. Compared with company design, user design is associated with stronger self-improvement and uncertainty as perceived by customers. Perceived self-improvement is positively related to purchase intention while perceived uncertainty undermines purchase intention. Moreover, for weak brands, perceived selfimprovement is significantly stronger in user design than company design, while for strong brands, this relationship is not significant.

Originality - This paper draws on mental accounting theory to study the perceived benefits and risks of user design of utilitarian products, and highlight the double-edged effects of user design on customers' perceived value and purchase decision. Our findings provided more rounded insights on user design of utilitarian products, complementing the one-sided view of customers' positive 
perceives of user design in unclassified product categories.

Keywords: User design, perceived self-improvement, perceived uncertainty, brand strength, mental accounting

Article classification: Research paper 


\section{Introduction}

User design for product development has become a popular innovation strategy in which companies obtain users' ideas to develop new products, and users create value alongside the company (Akman et al., 2019, Schreier et al., 2012). These products are called user-designed products in contrast with company-designed products (designed by company designers) (Hossain and Islam, 2015). LEGO, for example, creates user-designed products labelled as "designed by LEGO fans". User design has subtle effects on the psychology of users who have participated in the design (hereafter referred to as participating users), resulting in their strong feelings of accomplishment and consequently purchase intention for user-designed products (Franke et al., 2010, Troye and Supphellen, 2012). However, winning over nonparticipating users (hereafter referred to as customers) is even more important (Dahl et al., 2015, Song et al., 2021). To date, there are few studies on the effects of user design on customers' responses to it (Paharia and Swaminathan, 2019), and the effects on customers' perceived value and purchase intention (Bradonjic et al., 2019), and the results are inconclusive. Hence, this paper focuses on the research question: To what extent do design sources (i.e. user design and company design) affect customers' perceived value and purchase intention? By answering this research question, we aim to address the following research problems.

First, existing research on the effects of user design has mainly focused on customers' positive perceptions (e.g., perceived innovative ability, feeling of accomplishment) (Franke et al., 2010, Schreier et al., 2012), and rarely discussed the effects of user design on customers' negative perceptions, which are important in affecting customer's purchase intention. Drawing on mental accounting theory, we argue that gauging the overall value perceived by customers, including perceived benefit and risk, is key to understand their purchasing decisions (Soster et al., 2010, Thaler, 
2008). As user design and company design can be significantly different in product philosophy and product characteristics, they may affect value perceived by customers both differently, consequently influencing their purchase intention. Thus, understanding the effects of design sources on customers' overall perceived value - both positive and negative - is a valuable research pursuit.

Second, existing research has provided insights regarding the effects of user design but seldom focused on specific product categories (Fuchs et al., 2013). Although some scholars have pointed out that the effect of user design is weakened in product categories with high product complexity (Schreier et al., 2012) or in luxury products (Fuchs et al., 2013), more research is needed to explore the effects of user design in the context of specific product categories. For example, utilitarian and hedonic products are two typical product categories (Chitturi et al., 2007, Strahilevitz and Myers, 1998). User design is widely adopted in utilitarian products (Candi et al., 2016), as their consumption is universal as part of a necessity (Kakar, 2017). Hence, we focus on utilitarian products and the effects of user design in this paper. Building on prior research on customers' perceived value and utilitarian product purchasing (Kakar, 2017, Li et al., 2012, Young et al., 2012), we focus on perceived self-improvement (i.e., positive perceptions) and perceived uncertainty (i.e., negative perceptions) as important dimensions of perceived value of utilitarian products. We thus explore the effects of design sources on customers' perceived self-improvement and uncertainty, and consequently purchase intention of utilitarian products.

Finally, existing research has not adequately explored the role that brand attributes play in the effect of user design. Brand strength is a typical brand attribute, proving to have an effect on customers' purchasing decision (Moreau and Herd, 2010). The degree of brand strength (strong brand vs. weak brand) is associated with different risks in terms of product reliability (Ho-Dac et al., 2013, 
Smith and Park, 1992), which may moderate the effect of user design. Hence, brand strength is an important factor that companies need to consider when adopting user design. We further examine whether the relationship between design sources and customers' perceived value is affected by the degree of brand strength.

To address the above research problems, we develop a multiple mediation model to test the effects of design sources on purchase intention as mediated by customers' perceived selfimprovement and perceived uncertainty, and the moderating effect of brand strength on the effect of design sources on customers' perceived self-improvement. We adopted a two-study approach involving a laboratory experiment of 160 participants and an online experiment of 312 participants to test our research model. Overall, this paper makes a significant contribution to the marketing literature, especially improving our understanding of the effects of design sources on customers' perceptions and purchasing intention of utilitarian products. Specifically, we provided rounded insights by drawing on mental accounting theory (Thaler, 2008), engaging in mental processes to evaluate benefits against risks (Antonides et al., 2011), as well as taking into account the brand strength of utilitarian products. Hence, this paper contributes to a holistic understanding of the effects of design sources on purchase intention, which is much needed to complement the one-sided view of customers' positive perceptions of user design in the existing literature.

The structure of this paper is as follows: Section 2 reviews the studies on user design of utilitarian products, mental accounting theory and brand strength. Section 3 discusses the research model and hypotheses. The empirical results are analysed in Section 4. Section 5 discusses the theoretical implications, practical implications, limitations, and future research directions. 


\section{Theoretical background}

\subsection{User design of utilitarian products}

User design reflects the design philosophy where companies rely on users' participation to produce ideas for new products (von Hippel, 2005, Bradonjic et al., 2019). Using the design tools provided by companies (such as websites or mobile applications), participating users design products which are then developed into formal products by the companies (Dahl et al., 2015, Schreier et al., 2012). Through user design, companies create and manage interactions with participating users, who express their ideas and influence the direction of product innovation (Addis et al., 2021). Thus, user design is regarded as a source of creating product value (Bradonjic et al., 2019).

Existing research (see Table 1) has focused on the perceptions and behavioural intention of participating users. For instance, Fuchs et al. (2010) found that participating users feel they have a personal and direct impact on the company's product offerings. Recent research has considered the effects of user design on customers (Nishikawa et al., 2017, Paharia and Swaminathan, 2019). However, there are few studies on the effect of user design on customers' perceived value.

\section{Insert Table 1 about here}

Moreover, existing studies mainly focused on the effects of user design on customers' positive perceptions, and rarely discussed customers' potential negative perceptions. Clearly, user design is innovative and customer-oriented, enhancing customers' perceived innovative ability of the company (Schreier et al., 2012) and their feelings of empowerment and identification with the company (Dahl et al., 2015, Paharia and Swaminathan, 2019). However, several studies have mentioned that 
customers may not be in favour of user-designed products because participating users are not assumed to possess the necessary design skills to create high quality products (Fuchs et al., 2013, Nishikawa et al., 2017), but this has not been thoroughly examined. How customers perceive user design and how they evaluate the overall value of such products, both benefits and risks involved, are important questions.

Further, existing research on the effects of user design does not differentiate product categories, although scholars have warned that the effect of user design is weakened in the product category with high product complexity (Schreier et al., 2012, Song et al., 2021). Utilitarian products and hedonic products are two typical categories with their different characteristics of comsumption (Candi et al., 2016, Kakar, 2017). Hedonic products are ones whose consumption is primarily characterised by an affective and sensory experience of aesthetic or sensual pleasure, fantasy, and fun; utilitarian products are ones whose consumption is cognitively driven, instrumental, and goal-oriented and fulfils a functional task (Dhar and Wertenbroch, 2000). Consequently, utilitarian products are often labelled as practical or necessary (Mundel et al., 2018). In practice, user design is widely adopted in utilitarian products (Candi et al., 2016). The consumption of utilitarian products is universal, as it has been seen as a necessity (Kakar, 2017). Hence, this research will focus on user design of utilitarian products.

Finally, within the utilitarian product category, there is limited research examining the influence of the brand attributes of products on the effects of user design on customers' perceived value. This neglects the diverse brand images within utilitarian product category and fails to recognise that influence of brand attributes, which play an important role in purchasing process. In particular, brand strength is widely recognised as an influential factor of customers' purchasing decision (Chang and Tseng, 2015). In this paper, we will examine the moderating role of brand strength. 


\subsection{Mental accounting theory}

Mental accounting theory was developed from the prospect theory, arguing that individuals psychologically code, classify, and evaluate behavioural outcomes, and put benefits and risks into different mental accounts to make decisions through different mental calculation rules (Thaler, 2008). Mental accounting processes serve (at least) three purposes: to simplify decisions, to keep self-control when facing tempting consumption opportunities, and to maximise hedonic pleasure from decision outcomes (Zhang and Sussman, 2018). It provides a systematic way of viewing individuals' benefitrisk assessment: people pursue not the maximisation of utility in rational cognition but the maximisation of overall value in the process of psychological operation (Soster et al., 2010). This theory pinpoints the psychological cognitive process of positive and negative perceptions in decisionmaking, and it is widely used to explain consumption behaviour, such as household spending (Zhang and Sussman, 2018), usage of credit cards (Simester, 2001), and taxpayers' compliance (Muehlbacher et al., 2017).

From the perspective of mental accounting theory, measuring the overall value of a product is a key step for customers in making purchasing decisions (Soster et al., 2010). Customers use mental accounts to keep track of the benefits and risks associated with the purchase of products, and close the account with an overall gain (Soster et al., 2010). Weighing out the overall value of products, customers form the purchase intention (Prelec and Loewenstein, 1998). In this paper, we compare the characteristics of user design and company design of utilitarian products, and examine how they influence customers' perceived self-improvement (i.e., positive perceptions) and perceived uncertainty (i.e., negative perceptions). Overall, this paper constructs a multiple mediation model to explore the relationship between design sources, perceived self-improvement, perceived uncertainty, 
and purchase intention, as informed by mental accounting theory.

\subsection{Brand strength}

Brand strength is customers' perceptions of a certain brand in terms of its comprehensive strength, including equity, market position, innovation ability, etc (Muehlbacher et al., 2017). Drivers of brand strength including features of desirability, size, and uniqueness (Grohs et al., 2016). According to the brand signalling literature, uncertainty about product quality and performance creates risk (Erdem et al., 2006). To cope with this risk, customers rely on signals to indicate product quality and performance when purchasing (Ho-Dac et al., 2013). Brand strength has been found to be an especially strong and effective signal of product quality (Erdem et al., 2006).

Previous research has shown that brand strength reinforces customers' prior knowledge of the brand, and this has a significant influence on the process of value assessment about products (Lin and Sung, 2014). The literature in marketing research provides ample evidence of the benefits of strong brands (Glynn, 2010, Low and Lamb, 2000). For instance, strong brands enhance customers' perceived quality of, and confidence in, the product (Miyazaki et al., 2005). As different design sources may lead to complexity and uncertainty in customers' value assessments and purchase of products, the signal of brand strength may play an important role in their perception process. Previous research on the effect of user design has not provided any direct evidence about how brand strength moderates the effects of user design. Therefore, based on previous research, we propose that brand strength is an important factor that companies need to consider when adopting user design. By introducing the factor of brand strength, we attempt to examine how the effect of design sources on customers' perceived value would change under different degrees of brand strength. 


\section{Hypotheses}

\subsection{Design sources and perceived self-improvement}

Self-improvement is the tendency to pursue outcomes that contribute to the improvement of certain aspects of the self, including personal attributes or performance in the areas important to the self, such as the intellectual, moral, social, or physical self (Sedikides, 1999, Allard and White, 2015). Generally, people prefer to choose options that enable self-improvement (Moffitt et al., 2018). In the context of consumption, perceived self-improvement is defined as customers' perceptions about selfimprovement due to features of products (Moffitt et al., 2018).

The consumption of utilitarian products is cognitively driven, instrumental, and goal-oriented to fulfil a functional task (Strahilevitz and Myers, 1998), and it is often labelled as practical or necessary (Kakar, 2017). Utilitarian products that meet or exceed the practical needs of customers and achieve preventive goals can improve customer satisfaction (Chitturi et al., 2008). Customers' preference for such utilitarian products are caused by the spillover benefits the products bring to them, such as emotions of security and confidence (Chitturi et al., 2008, Halamish et al., 2008). This means that utilitarian products can trigger a positive perception about customers themselves beyond utility of products. Based on this, we postulate that utilitarian products with different design sources may lead to different degrees of customers' perceived self-improvement. As company designers are not necessarily consumers and users of utilitarian products, they are considered to lack the necessary understanding of customers' real needs (Poetz and Schreier, 2012). Customers believe that more innovative ideas may come from diverse and unconstrained participating users who understand their own needs than a team of company designers (Nishikawa et al., 2017, Schreier et al., 2012). User design increases the perceptions of a more creative outcome because of the chances of finding more 
outside-the-box contributions and therefore more innovative offerings (Huertas and Pergentino, 2020).

Furthermore, user design can also trigger positive perceptions about customers' social identity (Dahl et al., 2015, Paharia and Swaminathan, 2019). In this regard, Dahl et al. (2015) demonstrated that customers belong to the same social category of participating users; this implies that customers activate their "user identity" when encountering user-designed products. Customers would feel empowerment by vicariously being involved in the design process (Dahl et al., 2015, Paharia and Swaminathan, 2019). In addition, feelings of empowerment underlie customers' identification with the company (Dahl et al., 2015), which can strengthen customers' feelings of status, belongingness, and social identity (Brashear-Alejandro et al., 2016). In conclusion, we propose that compared with company design, user design enables customers to perceive stronger self-improvement. We hypothesise as follows:

H1: Customers have stronger perceived self-improvement with user design than with company design.

\subsection{Design sources and perceived uncertainty}

Perceived uncertainty is the extent to which customers are unable to accurately predict the outcome of a transaction due to information asymmetry (Milliken, 1987). Previous studies have classified perceived uncertainty into perceived seller quality uncertainty (refers to seller's actions such as seller hiding their true characteristics, making false promises, or defrauding) and perceived product quality uncertainty (refers to product condition being compromised), and explored the factors that influence different types of perceived uncertainty (Pavlou et al., 2007, Zhang et al., 2020). In this paper, we focus on the impact of design sources of utilitarian products on the customer's perceived 
uncertainty, which is related to the customer's judgement of product quality, i.e., perceived product quality uncertainty.

Previous research has highlighted that the consumption of utilitarian products aligns well with prevention focus (Chitturi et al., 2007), which means customers focus on risk aversion in purchasing and avoid product-related uncertainties (Kivetz and Zheng, 2017). Based on previous research on the flexibility and uncontrollability of user design (Cui and $\mathrm{Wu}, 2016$ ), we postulate that utilitarian products with user design are associated with stronger perceived uncertainty. Fuchs et al. (2013) pointed out that whereas the company has continuously proven the ability of participating users, customers may perceive these users to lack the relevant expertise. Similarly, Schreier et al. (2012) found that customers associate participating users with less design expertise compared with professionals employed by unknown brands. Customers might find user-designed utilitarian products to be risky as it lacks social proof. Being vigilant and risk averse in comsuption of utilitarian products, customers will have strong perceived uncertainty as the user design are not aligned with their goals of safety and risk aversion. Conversely, a company design is promoted as an expert product, it provides social proof or validation of a good product (Moreau and Herd, 2010), and helps customers to make inferences about favorable product quality and social appropriateness (Song et al., 2021), thereby reducing perception uncertainty. By considering these findings, we propose that compared with company design, user design can trigger stronger perceived uncertainty. Therefore, we hypothesise as follows:

H2: Customers have stronger perceived uncertainty with user design than with company design. 


\subsection{Mediating roles of perceived self-improvement and perceived uncertainty}

As demonstrated above, user design is often perceived by customers as innovative (Fuchs et al., 2013), leading to stronger self-improvement, as perceived by customers, compared with company design. In the context of consumption, customers show a preference for the options that enable individuals to improve themselves. These options can fall into the self-improvement category (Allard and White, 2015). As people have a desire for self-improvement in consumption (Sedikides, 1999), they would have a purchase intention when they have perceptions of self-improvement with the specific product (Moffitt et al., 2018). Therefore, we propose that perceived self-improvement is positively related to purchase intention. we hypothesise as follows:

H3a: Perceived self-improvement is positively related to purchase intention.

Based on mental accounting theory, perceived self-improvement is a positive perception of customers in the decision-making process (Moffitt et al., 2018, Soster et al., 2010). As proposed above, different design sources make customers have different perceived self-improvement. According to social cognitive theory, individuals' perceptions of situational cues will further produce the intention of follow-up behaviour (Bandura, 1986). Hence, in connection with the positive relationship between perceived self-improvement and purchase intention, we propose that design sources will affect customers' purchase intention through perceived self-improvement. We hypothesise as follows:

H3b: Perceived self-improvement mediates the effects of design sources on purchase intention. 
In order to reduce the risk and avoid the possible loss, people tend to choose the option with less uncertainty (Dimoka et al., 2012). When it is difficult for customers to determine the quality, style, and other features of the product, their consumption desire will be restrained (Zhang et al., 2020). Being vigilant and risk averse in purchasing utilitarian products (Kakar, 2017), customers will avoid buying products with strong perceived uncertainty. This helps customers meet their goals of avoiding risk and losses (Kivetz and Zheng, 2017). Hence, we propose that perceived uncertainty is negatively related to purchase intention. We hypothesise as follows:

H4a: Perceived uncertainty is negatively related to purchase intention.

Perceived uncertainty is a negative perception of customer in the decision-making process based on mental accounting theory (Milliken, 1987). Design sources make customers have different perceived uncertainty, which would further affect customers' behaviour intention according to social cognitive theory (Bandura, 1986). With the consideration of the relationship between design sources and perceived uncertainty, we propose that design sources will affect customers' purchase intention through perceived uncertainty. We hypothesise as follows:

H4b: Perceived uncertainty mediates the relationship between design sources and purchase intention.

\subsection{The moderating role of brand strength}

User-designed products are often considered as creative due to input by users from outside the 
company (Nishikawa et al., 2017); company-designed products represent the real product level of the brand (Hsu et al., 2018). Different degrees of brand strength will make customers have different perceptions of product quality (Lin and Sung, 2014). Therefore, the effects of company design and user design on customers' perceived self-improvement may change under different conditions of brand strength.

Under the condition of strong brands, customers consider that the company, which already provides substantial assurance (Ho-Dac et al., 2013), has the resources to employ high-level designers and elite experts. Customers believe in experts' professional knowledge and skills and therefore trust in the utility of the products (Moreau and Herd, 2010). Different from the participating users outside the company, internal designers of strong brands would be considered to be more strictly required by the company, and their designs are more representative of the real level of strong brands (Hsu et al., 2018, Muehlbacher et al., 2017). Therefore, compared with user design, company design may bring high levels of customer confidence, leading to customers having a higher level of perceived selfimprovement.

Under the condition of weak brands, customers believe that the overall reputation of the company is relatively weak (Smith and Park, 1992). Due to the relatively low expectations of the company, customers may think that the products designed by the company are based on the traditional needs of the mass market to guarantee sales and profit (von Hippel, 2005). However, such products cannot meet the diversified needs of customers, and the design level and quality are less credible than those of strong brands due to the lack of a credible brand signal (Erdem et al., 2006). Customers pay more attention to the unique and functional factors of the products rather than brand identification under the condition of weak brands (Lam et al., 2012). Therefore, they tend to have more positive 
perceptions about products designed by participating users, which are seen to be customer-oriented and creative (Schreier et al., 2012). We propose that under the condition of weak brands, customers have lower levels of trust and confidence in company design, while the novelty and uniqueness of user design may satisfy their utility needs and emotional needs and so encourage them to produce stronger perceived self-improvement. Therefore, we hypothesise as follows.

H5a: Under the condition of a strong brand, company design (compared with user design) promotes stronger perceived self-improvement.

H5b: Under the condition of a weak brand, user design (compared with company design) promotes stronger perceived self-improvement.

Insert Figure 1 about here

\section{Methods}

\subsection{Research design}

We adopted a two-study approach - a laboratory experiment (Study 1) and an online experiment (Study 2). Two common utilitarian products, a T-shirt and a chair, were used as the experimental stimulus in Study 1 and Study 2 respectively (see Appendix). These products were used because they often involve user design. For example, companies such as Threadless (apparel company) and IKEA (furniture company) commonly employ user design for these two types of products. Moreover, customers are familiar with the use and purchase of T-shirts and chairs. Study 1 aimed to examine the effects of design sources on customers' perceived self-improvement and perceived uncertainty, and consequently purchase intention. Study 2 aimed to strengthen the generalizability of the results by 
validating the hypotheses in the context of chair purchasing and further tested the moderating role of brand strength.

\subsection{Study 1}

\subsubsection{Pretest of stimulus}

Before beginning our investigation, we tested the appropriateness of the T-shirts as experimental stimulus through pretest. Previous research has noted that a product may processes a balance of hedonic and utilitarian features, and product price may influence customers' judgments of product attributes (Dhar and Wertenbroch, 2000). We examined customers' judgments of product attributes by applying different prices to the same product.

We recruited 60 online customers as respondents from an experimentation study platform (https://www.wjx.com). They were randomly divided into six groups to measure their judgement of attributes of products at different prices. We designed two T-shirts with similar styles and placed images of both on the same webpage. The two T-shirts were tagged with price tags of $\$ 10, \$ 50$, and $\$ 150$ on different webpages and shown to three groups of participants. The respondents were asked to evaluate the attributes of the T-shirts with a seven-point scale ("indicate the extent you think this product is hedonic or utilitarian: $1=$ hedonic product, $7=$ utilitarian product") (Dhar and Wertenbroch, 2000). The results of ANOVA showed that respondents who viewed the T-shirts with the $\$ 10$ price tag scored the highest $\left(\mathrm{M}_{\$ 10}=6.00, \mathrm{M}_{\$ 50}=4.55, \mathrm{M}_{\$ 150}=2.15, \mathrm{~F}=50.411, \mathrm{p}<0.001\right)$. Therefore, $\mathrm{T}-$ shirts with $\$ 10$ price tags could be used as experimental stimuli for this study.

\subsubsection{Participants and procedure}

We conducted Study 1 in a behavioural study laboratory in the university and recruited 160 
postgraduate students as respondents $(47.5 \%$ males $)$. These respondents were all mature students $\left(\mathrm{M}_{\mathrm{age}}=23.1\right.$ years $)$ and independently recruited university-wide. They had T-shirt purchase experience. Thus, they were suitable samples for this study. Prior to conduct the laboratory experiment, we obtained institutional ethical approval from the university.

The respondents were randomly assigned to a 2 (design sources: user design vs. company design) $\times 2$ (designer information: with designer information vs. without designer information) betweensubject design. All the respondents were first informed of the following scenario: "You want to buy a T-shirt for yourself. There are two different brands of T-shirts that have attracted you." Next, the pictures of two T-shirts with $\$ 10$ price tags labelled as Brand A and Brand B respectively were displayed on the screen. Respondents with designer information were informed in a text that the Tshirt of Brand A was a product of company design, and the T-shirt of Brand B was a product of user design, while respondents without designer information did not receive such information.

After observation of the two T-shirts, the respondents completed the measurement scales of perceived self-improvement, perceived uncertainty, and purchase intention. The items of all the constructs were adapted from existing scales to fit our context using a seven-point Likert scale (see Table 2). Perceived self-improvement was adapted from Allard and White (2015), perceived uncertainty was adapted from Weathers et al. (2007), and purchase intention was adapted from Gilly et al. (1998).

Insert Table 2 about here

Respondents in the group of user design responded to the T-shirt of Brand A, while those in the group of company design responded to the T-shirt of Brand B. The assumption was that if there was 
no significant difference in perceived self-improvement and perceived uncertainty between the two groups without designer information, while there were significant differences in perceived selfimprovement and perceived uncertainty between the two groups with designer information, the influence of T-shirt style preference on purchase intention would be excluded.

\subsubsection{Results}

The results of confirmatory factor analysis (CFA) showed that the measurement model fitted the data reasonably well $\left(\chi^{2} / d f=1.060 ; \mathrm{GIF}=0.952 ; \mathrm{CFI}=0.997 ; \mathrm{TLI}=0.997 ; \mathrm{RMSEA}=0.019\right)$. As shown in Table 3 , the composite reliability ranged from 0.793 to 0.919 , exceeding the threshold value of 0.7. The Cronbach's $\alpha$ coefficients ranged from 0.792 to 0.919 . These results indicate an acceptable level of construct reliability. Moreover, all the factor loadings of the items ranged from 0.666-0.891. Convergent validity is considered to be acceptable if the factor loadings are above 0.5 . Thus, the convergent validity of our construct measurement is acceptable. Furthermore, we also examined the discriminant validity of each construct. The average variance extracted (AVE) values range from 0.563-0.741, exceeding the conventional minimum of 0.5 . As shown in Table 4 , The square root of each AVE is greater than the corresponding correlation coefficients, suggesting that discriminant validity is satisfactory in our study.

Insert Tables 3 and Table 4 about here

We performed statistical analyses to access the severity of common method bias. First, the results of Harmon one-factor test showed that three factors are present and the most covariance explained by one factor is $37.874 \%$ (Podsakoff and Organ, 1986). Second, we performed CFA with a single latent 
factor (Podsakoff et al., 2003), a very poor model fit was observed $\left(\chi^{2} / d f=10.214 ; \mathrm{GIF}=0.600 ; \mathrm{CFI}\right.$ $=0.571 ; \mathrm{TLI}=0.464 ; \mathrm{RMSEA}=0.241)$. Third, followed Podsakoff et al. $(2003)$ and Williams et al . (2003), we included in the CFA model a common method factor whose indicators included all the principal constructs' indicators and calculated each indicator's variances substantively explained by the principal constructs and by the method. The results demonstrate that the ratio of substantive variance to method variance is about 33:1. These results indicating that the method is unlikely to be a serious concern for this study.

The results of a $2 \times 2$ ANOVA on perceived self-improvement showed that there was an effect of design sources on perceived self-improvement $(\mathrm{F}(1,156)=80.606, p<0.001)$, and a significant interaction effect between design sources and designer information on perceived self-improvement $(\mathrm{F}(1,156)=84.178, p<0.001)($ see Table 5$)$. Further analysis (see Figure 2$)$ showed no significant difference in perceived self-improvement for respondents without designer information $\left(\mathrm{M}_{\text {company }}=\right.$ $\left.4.100, \mathrm{M}_{\text {user }}=4.075 ; \mathrm{F}(1,156)=0.020, \mathrm{p}>0.5\right)$. In contrast, respondents with designer information had stronger perceived self-improvement for user design than for company design $\left(\mathrm{M}_{\text {company }}=3.381\right.$, $\left.\mathrm{M}_{\text {user }}=5.688 ; \mathrm{F}(1,156)=153.64, p<0.001\right)$. These results support $\mathrm{H} 1$.

\section{Insert Table 5 and Figure 2 about here}

The results of a $2 \times 2$ ANOVA on perceived uncertainty showed that there was an effect of design sources on perceived uncertainty $(\mathrm{F}(1,156)=7.837, p<0.01)$, and a significant interaction effect between design sources and designer information on perceived uncertainty $(\mathrm{F}(1,156)=10.102, p<$ 0.001) (see Table 6). Further analysis (see Figure 3) showed no significant difference in perceived uncertainty for respondents without designer information $\quad\left(\mathrm{M}_{\text {company }}=4.069, \mathrm{M}_{\mathrm{user}}=4.013 ; \mathrm{F}(1,156)\right.$ 
$=0.070, p>0.05$. In contrast, respondents with designer information had stronger perceived uncertainty for user design than for company design $\left(\mathrm{M}_{\text {company }}=3.525, \mathrm{M}_{\text {user }}=4.413 ; \mathrm{F}(1,156)=\right.$ 17.96, $p<0.001)$. These results supported $\mathrm{H} 2$.

Insert Table 6 and Figure 3 about here

We also analysed the simple main effect of design sources corresponding to designer information. The results showed that for company design, customers with designer information (vs. without designer information $)$ had lower perceived self-improvement $\left(\mathrm{M}_{\text {with information }}=3.381, \mathrm{M}_{\text {without information }}\right.$ $=4.100, \mathrm{~F}(1,156)=16.003, p<0.000)$ and lower perceived uncertainty $\left(\mathrm{M}_{\text {with information }}=3.525\right.$, $\left.\mathrm{M}_{\text {without information }}=4.069, \mathrm{~F}(1,156)=6.707, p<0.05\right)$. For user design, customers with designer information (vs. without designer information) had stronger perceived self-improvement $\left(\mathrm{M}_{\text {with }}\right.$ information $\left.=5.688, \mathrm{M}_{\text {without information }}=4.075, \mathrm{~F}(1,156)=80.547, p<0.000\right)$ and stronger perceived uncertainty $\left(\mathrm{M}_{\text {with information }}=4.413, \mathrm{M}_{\text {without information }}=4.013, \mathrm{~F}(1,156)=5.630, p<0.05\right)$. These results indicate that when customers were informed with design sources, they had higher perceived self-improvement and perceived uncertainty with user design compared with company design. This provides further support for $\mathrm{H} 1$ and $\mathrm{H} 2$.

We estimated a mediation model using PROCESS model 4 (Hayes, 2013) to test the mediating role of perceived self-improvement and perceived uncertainty between design sources and purchase intention (see Figure 4). As expected, the results showed perceived self-improvement was positively related to purchase intention $(95 \%$ CI: LLCI $=0.098, \mathrm{ULCI}=0.395)$, while perceived uncertainty was negatively related to purchase intention $(95 \% \mathrm{CI}$ : $\mathrm{LLCI}=-0.502, \mathrm{ULCI}=-0.189)$; both perceived self-improvement and perceived uncertainty played significant mediating roles. The mediating effects 
were $0.286(95 \%$ CI: LLCI $=0.124, \mathrm{ULCI}=0.504)$ and $-0.146(95 \% \mathrm{CI}: \mathrm{LLCI}=-0.301, \mathrm{ULCI}=-$ 0.041) respectively. After controlling for the mediating variables, the direct effect of design sources on customers' purchase intention was not significant $(95 \% \mathrm{CI}$ : LLCI $=-0.345, \mathrm{ULCI}=0.335)$. Thus, H3a, H3b, H4a and H4b were supported.

Insert Figure 4 about here

\subsection{Study 2}

\subsubsection{Pretest of stimulus}

We tested the appropriateness of the chairs as experimental stimulus through pretest. We designed two chairs with similar styles, and recruited 97 undergraduates to rate their style preference of these two chairs (e.g., How much do you like the style of this chair? 1 = "not at all", 7 = "very much"). The result $\left(\mathrm{M}_{\mathrm{Brand} A}=4.030, \mathrm{M}_{\mathrm{Brand} \mathrm{B}}=3.790 ; \mathrm{t}(96)=1.628, p>0.05\right)$ showed that there was no significant difference of preference between these two types of chairs. Based on this pretest, we used these two chairs as the stimulus to exclude the possible effect of style preference on the results. Similar to Study 1 , we placed images of these chairs with price tags of $\$ 100, \$ 300$, and $\$ 500$ on three webpages and shown to three groups of customers recruited from online experimentation study platform. The results of ANOVA showed that customers who viewed the chairs with the $\$ 100$ price tag scored the highest ("indicate the extent you think this product is hedonic or utilitarian: $1=$ hedonic product, $7=$ utilitarian product") $\left(\mathrm{M}_{\$ 100}=5.85, \mathrm{M}_{\$ 300}=4.05, \mathrm{M}_{\$ 500}=2.10, \mathrm{~F}=61.408, \mathrm{p}<0.001\right)$. Therefore, chairs with $\$ 100$ price tags could be used as experimental stimuli for this study. 


\subsubsection{Participants and procedure}

We conducted Study 2 in an online experimentation study platform with 312 online customers as respondents to expand the sample size and diversity of the respondents. The experimentation study platform (https://www.wjx.com) was commissioned to randomly select 350 online customers as respondents to complete this study (a fee equivalent to $\$ 1$ was paid to each participate). After the test, 26 respondents were excluded from the analysis because they provided answers unreasonably rapidly. Another 12 respondents were eliminated due to missing data. Finally, a total of 312 valid responses (49.7\% males, $\mathrm{M}_{\mathrm{age}}=31.04$ years) were used in the analysis. All the respondents were randomly assigned to a 2 (design sources: user design vs. company design) $\times 2$ (brand strength: strong brand vs. weak brand) between-subject design. The distribution of respondent demographics is summarised in Table 7.

Insert Table 7 about here

Respondents were asked to make a chair purchase on the virtual shopping platform and then complete the questionnaire. All respondents were given the following scenario: "You want to buy a chair. There are two different brands of chairs available in this online shopping website". Next, the pictures of two chairs with $\$ 10$ price tags labelled as Brand A and Brand B respectively were displayed. Respondents received information about design sources in a text: "The chair of Brand A is a product of company design; the chair of Brand B is a product of user design". In addition, the respondents of different groups of brand strength also obtained the corresponding brand strength information in the text:

For the group of strong brand: Brand $A$ and Brand B are leading brands of furniture products. 
They are well-known and reputable. They have been widely recognised by customers as having highlevel product quality and service image. For the group of weak brand: Brand A and Brand B have just entered the field of furniture production. They are both new brands, and their popularity is not very high. The products and services sold are in line with industry standards.

After reading all the information, the respondents completed the measurement scales. The scales of perceived self-improvement, perceived uncertainty, and purchase intention were the same as those in Study 1. The scale of brand strength (Cronbach's $\alpha=0.967$ ) was adapted from Sheng Goh et al. (2013) ("Please rate the brand according to your judgment: $1=$ Weak brand, $7=$ Strong brand"; "Please rate the brand according to your judgment: 1=Ordinary brand, 7=Leading brand"). Respondents in the group of company design responded to the chair of Brand A, while those in the group of user design responded to the chair of Brand B.

\subsubsection{Results}

The results of the confirmatory factor analysis showed that the measurement model fitted the data reasonably well $\left(\chi^{2} / d f=1.921 ; \mathrm{GIF}=0.929 ; \mathrm{CFI}=0.971 ; \mathrm{TLI}=0.672 ; \mathrm{RMSEA}=0.047\right)$. All the indicators of each construct met the 0.6 factor loadings threshold, and all variables met the requirement of AVE $>0.5$ as shown in Table 8. Table 9 shows that the square roots of AVE were greater than the correlation between variables. Reliability in the forms of composite reliability and Cronbach's $\alpha$ coefficients for each variable exceeded 0.7 .

Insert Tables 8 and Table 9 about here

The results of Harman's one-factor test (Podsakoff and Organ, 1986) showed that the first factor 
explained $44.962 \%$ of the total variance, which was lower than the reference standard of $50 \%$. The results of the single latent factor method (Podsakoff et al., 2003) showed a very poor model fit $\left(\chi^{2} / d f\right.$ $=43.911 ; \mathrm{GIF}=0.391 ; \mathrm{CFI}=0.455 ; \mathrm{TLI}=0.318 ; \mathrm{RMSEA}=0.371)$. In addition, the results of unmeasured method factor approach (Williams et al., 2003, Podsakoff et al., 2003) showed the ratio of substantive variance to method variance is about $26: 1$. Hence, there is no serious common method bias for the measures.

The results of an independent samples t-test with brand strength as the dependent variable showed that the score of brand strength of products in the group of strong brand was significantly higher than that in the group of weak brand $\left(\mathrm{M}_{\text {strong brand }}=4.946, \mathrm{M}_{\text {weak brand }}=3.151, \mathrm{t}=11.486, p<\right.$ 0.001). The results indicated the success of the manipulation of brand strength.

The results of ANOVA with design sources as a between-subjects factor revealed that participants have stronger perceived self-improvement with user-design than with company design $\left(\mathrm{M}_{\mathrm{user}}=4.823\right.$, $\left.\mathrm{M}_{\text {company }}=3.340 ; \mathrm{F}(1,311)=100.465, p<0.001\right)$. However, participants also have stronger perceived uncertainty with user-design than with company design $\left(\mathrm{M}_{\mathrm{user}}=4.655, \mathrm{M}_{\text {company }}=3.974 ; \mathrm{F}(1,311)=\right.$ 27.709, $p<0.001)$. H1 and H2 were supported.

We estimated a mediation model using PROCESS model 4 (Hayes, 2013). As expected, the results showed perceived self-improvement was positively related to purchase intention (95\% CI: LLCI $=0.098$, ULCI $=0.395)$, while perceived uncertainty was negatively related to purchase intention (95\% CI: LLCI $=-0.502, \mathrm{ULCI}=-0.189)$; both perceived self-improvement and perceived uncertainty played significant mediating roles. The mediating effects were 0.286 (95\% CI: LLCI $=$ $0.124, \mathrm{ULCI}=0.504)$ and $-0.146(95 \% \mathrm{CI}: \mathrm{LLCI}=-0.301, \mathrm{ULCI}=-0.041)$ respectively. After controlling for the mediating variables, the direct effect of design sources on customers' purchase 
intention was not significant $(95 \% \mathrm{CI}$ : LLCI $=-0.345, \mathrm{ULCI}=0.335)$. Thus, H3a, H3b, H4a and H4b were supported.

To examine the moderation hypotheses, we used the PROCESS model 1 (Hayes, 2013) to test the moderating effect of brand strength. The results are illustrated in Table 10. In Model 1, there was a main effect of design sources on perceived self-improvement $(95 \%$ CI: LLCI $=1.691$, ULCI $=$ 2.137), and this effect was moderated by brand strength (95\% CI: LLCI $=-2.167$, ULCI $=-1.537)$. Further analysis (see Figure 5) showed that under the condition of strong brand, there was no significant difference in perceived self-improvement between respondents in the group of user design and the group of company design $\left(\mathrm{M}_{\mathrm{user}}=4.442, \mathrm{M}_{\text {company }}=4.349 ; \mathrm{F}(1,308)=0.289, p>0.05\right)$, so H5a was not supported. However, under the condition of weak brand, respondents in the group of user design had stronger perceived self-improvement than those in the group of company design $\left(\mathrm{M}_{\text {user }}=5.205, \mathrm{M}_{\text {company }}=2.330 ; \mathrm{F}(1,308)=285.359, p<0.000\right)$, H5b was supported. In addition, the results indicated the effect of design sources on perceived uncertainty $(95 \% \mathrm{CI}$ : LLCI $=0.326$, $\mathrm{ULCI}=0.942)$, and this effect was not moderated by brand strength $(95 \%$ CI: LLCI $=-0.199$, ULCI $=0.418)$.

Insert Table 10 and Figure 5 about here

\section{General discussion}

Based on mental accounting theory, this paper constructed a multiple mediation model with perceived self-improvement and perceived uncertainty as mediators between design sources and customers' purchase intention in the context of utilitarian product purchasing. Our findings from a 
laboratory experiment and an online experiment reveal that, compared with company design, user design leads customers to produce stronger perceived self-improvement and perceived uncertainty. Perceived self-improvement is positively related to customers' purchase intention, while perceived uncertainty is negatively related to purchase intention. In addition, perceived self-improvement and perceived uncertainty mediate the relationship between design sources and purchase intention.

The findings also reveal the moderating role of brand strength in the relationship between design sources and perceived self-improvement. Specifically, under the condition of a weak brand, user design promotes stronger perceived self-improvement compared with company design. However, under the condition of a strong brand, customers' perceived self-improvement as associated with user design was not significantly stronger than that associated with company design. We argue that this result may be caused by the effect of brand association (Miyazaki et al., 2005, Glynn, 2010). Brand association encourages customers to believe that the stronger the brand strength, the stronger the comprehensive strength of the company (Miyazaki et al., 2005). Customers have sufficient confidence in the strong brands' product quality and product management, which makes them less sensitive to the difference in perceptions between company-designed products and user-designed products. In addition, customers purchase products with strong brands not only for the higher quality of the products and services but also for the social status and self-image given by the strong brand (Lin and Sung, 2014). As a result, the positive effect of user design may be weakened, leading to no significant difference in perceived self-improvement between user design and company design.

\subsection{Theoretical contributions}

From a theoretical perspective, this paper contributes to the literature in several ways. First, in the past, research has analysed the participating users' motivations to engage in user-design activities 
as well as their preference for user-designed products (Roberts et al., 2014, Dahl et al., 2015, Troye and Supphellen, 2012). However, the primary goal of this research is different. Based on mental accounting theory, we look at how customers perceive the value difference between products with different design sources (i.e., user design vs. company design) and, how design sources affect customers' perceived values and purchase intention. Importantly, compared with previous studies that only suggested customers' positive perception of user design (Dahl et al., 2015), this paper reveals that customers' perceived values of user design are not always positive but can be negative as well. This means that user design could be a double-edged sword: while enhancing perceived selfimprovement, use design also increases perceived uncertainty. Our findings help to understand the effects of user design objectively and provide more rounded understanding, complementing existing research.

Second, we focus on utilitarian products and explore the impact of design sources by considering the characteristics of utilitarian products purchasing. Most relevant research have drawn general conclusions in the context of unclassified product categories. In this paper, we explore the different perceptions that different design sources of utilitarian products bring to customers, based on the analysis of the features of consumption of utilitarian products. Specifically, we constructed a multiple mediation model from the perspective of customers' risk-benefit analysis, and demonstrated that utilitarian products with user design is associated with stronger self-improvement and uncertainty as perceived by customers compared with company design. The findings also provide a lens through which to explain the inconsistent conclusion of the effect of user design in previous research (Fuchs et al., 2013) - differences in positive and negative perceptions of user design may vary across product categories. 
A final contribution of this paper is that it extends the previous literature on the effectiveness of user design by examining the moderating effect of brand strength in the relationship between design sources and perceived self-improvement. Previous research has focused on the moderators regarding customers' perceptions or product attributes. For instance, Dahl et al. (2015) highlighted the important role of perceived similarity to participating users as a moderator of the positive effect of user design, and Costa and Coelho do Vale (2018) suggested that user design is particularly beneficial to low-complexity products. However, many of the moderators concerned with brand attributes remain under explored. By suggesting brand strength as an important attribute of brand (Lin and Sung, 2014), this research builds on and extends the previous research, showing that brand strength leads to a change in the relationship between design sources and perceived self-improvement. The findings broaden the understanding of moderators of the effect of user design and further make the multiple mediating mechanism more explanatory.

\subsection{Practical implications}

This research provides practitioners with insights into the application of user design as well as the marketing of user-designed utilitarian products. The findings highlight that user design is associated with stronger perceived self-improvement, which further enhances purchase intention. By including a number of innovative features in user design, companies could take advantage of the advertising stimulus and enhance customers' perceived self-improvement in user-designed utilitarian products. In particular, companies may choose the types of utilitarian products that facilitate more self-improvement features as the objectives of user design, such as decorative personal goods (e.g., mobile phone case) rather than small everyday tools (e.g., kitchen cleaning items). In addition, the insights into the moderating role of the brand strength are meaningful to weak brands so that these 
companies can enhance the product advantages through user design. This research also highlights the fact that user design is associated with stronger perceived uncertainty. Practitioners need to be aware of the potential negative consequences of adopting user design. In order to reduce customers' negative perceptions, companies should consider customers' cognitive habits and product knowledge when choosing a type of utilitarian product for user design, as perceived uncertainty undermines purchase intention. Thus, practitioners should focus on the reduction of customers' perceived potential risks and losses, and should provide customers with more ways to understand the products.

\subsection{Limitations and future research}

This research has a few limitations that offer avenues for future research. First, this research has focused on two mediators (i.e., perceived self-improvement and perceived uncertainty) based on the perspective of benefit-risk from mental accounting theory. In fact, customers' perceived value of products is diverse. Meanwhile, the kinds of customers' perceptions about product may change in different contexts of product categories. It would be interesting to explore the variables regarding customers' perceptions from different theoretical perspectives or in the context of other product categories, and thereby obtain a more comprehensive understanding of the underlying mechanisms between design sources and customers' purchase intention. Second, this research examined the moderating role of brand strength, it would be interesting to further investigate other related features, such as - whether other brand attributes, or product categories and the types of customers may moderate the relationship between design sources and perceived value. Future work could expand this research by investigating the moderating roles of such factors. Third, we collected data on respondents' purchase intention in both studies. Although purchase intention can be used as an indicator of purchase behaviour (Lee and Lee, 2015), actual purchase data are more accurate in 
measuring purchase decision. Future research could adopt objective indicators such as transactional data to enrich the outcomes of customer behaviours and test the research model with more types of utilitarian products. 


\section{References}

Addis, M., Miniero, G. and Ricotta, F. (2021), "Value co-production made easy: the role of fantastical thinking", European Journal of Marketing, Vol. 55 No. 1, pp. 163-192.

Akman, H., Plewa, C. and Conduit, J. (2019), "Co-creating value in online innovation communities", European Journal of Marketing, Vol. 53 No. 6, pp. 1205-1233.

Allard, T. and White, K. (2015), "Cross-Domain Effects of Guilt on Desire for Self-Improvement Products", Journal of Consumer Research, Vol. 42 No. 3, pp. 401-419.

Antonides, G., de Groot, I.M. and van Raaij, W.F. (2011), "Mental budgeting and the management of household finance", Journal of Economic Psychology, Vol. 32 No. 4, pp. 546-555.

Bandura, A. (1986), Social Foundations of Thought and Action: A Social Cognitive Theory, Prentice Hall, New Jersey.

Bradonjic, P., Franke, N. and Luthje, C. (2019), "Decision-makers' underestimation of user innovation", Research Policy, Vol. 48 No. 6, pp. 1354-1361.

Candi, M., van den Ende, J. and Gemser, G. (2016), "Benefits of Customer Codevelopment of New Products: The Moderating Effects of Utilitarian and Hedonic Radicalness", Journal of Product Innovation Management, Vol. 33 No. 4, pp. 418-434.

Chang, A.H. and Tseng, T.H. (2015), "Consumer evaluation in new products: the perspective of situational strength", European Journal of Marketing, Vol. 49 No. 5-6, pp. 806-826.

Chitturi, R., Raghunathan, R. and Mahajan, V. (2007), "Form versus function: How the intensities of specific emotions evoked in functional versus hedonic trade-offs mediate product preferences", Journal of Marketing Research, Vol. 44 No. 4, pp. 702-714.

Chitturi, R., Raghunathan, R. and Mahajan, V. (2008), "Delight by design: The role of hedonic versus utilitarian benefits", Journal of Marketing, Vol. 72 No. 3, pp. 48-63.

Costa, C. and Coelho do Vale, R. (2018), "To tell or not to tell? The impact of communicating consumer participation in new product development", Journal of Product \& Brand Management, Vol. 27 No. 2, pp. 158-171.

Cui, A.S. and Wu, F. (2016), "Utilizing customer knowledge in innovation: antecedents and impact of customer involvement on new product performance", Journal of the Academy of Marketing Science, Vol. 44 No. 4, pp. 516-538. 
Dahl, D.W., Fuchs, C. and Schreier, M. (2015), "Why and When Consumers Prefer Products of UserDriven Firms: A Social Identification Account", Management Science, Vol. 61 No. 8, pp. 19781988.

Dhar, R. and Wertenbroch, K. (2000), "Consumer choice between hedonic and utilitarian goods", Journal of Marketing Research, Vol. 37 No. 1, pp. 60-71.

Dimoka, A., Hong, Y.L. and Pavlou, P.A. (2012), "On Product Uncertainty in Online Markets: Theory and Evidence", Mis Quarterly, Vol. 36 No. 2, pp. 395-426.

Erdem, T., Swait, J. and Valenzuela, A. (2006), "Brands as signals: A cross-country validation study", Journal of Marketing, Vol. 70 No. 1, pp. 34-49.

Franke, N., Schreier, M. and Kaiser, U. (2010), "The "I Designed It Myself" Effect in Mass Customization", Management Science, Vol. 56 No. 1, pp. 125-140.

Fuchs, C., Prandelli, E. and Schreier, M. (2010), "The Psychological Effects of Empowerment Strategies on Consumers' Product Demand", Journal of Marketing, Vol. 74 No. 1, pp. 65-79.

Fuchs, C., Prandelli, E., Schreier, M. and Dahl, D.W. (2013), "All That Is Users Might Not Be Gold: How Labeling Products as User Designed Backfires in the Context of Luxury Fashion Brands", Journal of Marketing, Vol. 77 No. 5, pp. 75-91.

Gilly, M.C., Graham, J.L., Wolfinbarger, M.F. and Yale, L.J. (1998), "A dyadic study of interpersonal information search", Journal of the Academy of Marketing Science, Vol. 26 No. 2, pp. 83-100.

Glynn, M.S. (2010), "The moderating effect of brand strength in manufacturer-reseller relationships", Industrial Marketing Management, Vol. 39 No. 8, pp. 1226-1233.

Grohs, R., Raies, K., Koll, O. and Muhlbacher, H. (2016), "One pie, many recipes: Alternative paths to high brand strength", Journal of Business Research, Vol. 69 No. 6, pp. 2244-2251.

Halamish, V., Liberman, N., Higgins, E.T. and Idson, L.C. (2008), "Regulatory focus effects on discounting over uncertainty for losses vs. gains", Journal of Economic Psychology, Vol. 29 No. 5, pp. 654-666.

Hayes, A.F. (2013), Introduction to mediation, moderation, and conditional process analysis, Guilford Publications, New York.

Ho-Dac, N.N., Carson, S.J. and Moore, W.L. (2013), "The Effects of Positive and Negative Online Customer Reviews: Do Brand Strength and Category Maturity Matter?", Journal of Marketing, Vol. 77 No. 6, pp. 37-53. 
Hossain, M. and Islam, K.M.Z. (2015), "Generating Ideas on Online Platforms: A Case Study of "My Starbucks Idea", Arab Economic and Business Journal, Vol. 10 No. 2, pp. 102-111.

Hsu, C.-L., Chen, Y.-C., Yang, T.-N., Lin, W.-K. and Liu, Y.-H. (2018), "Does product design matter? Exploring its influences in consumers' psychological responses and brand loyalty", Information Technology \& People, Vol. 31 No. 3, pp. 886-907.

Huertas, M.K.Z. and Pergentino, I. (2020), "The effect of "co-creation with consumers" claims on purchase intention: The moderating role of product category performance information", Creativity and Innovation Management, Vol. 29, pp. 75-89.

Kakar, A.K.S. (2017), "Why do users prefer the hedonic but choose the Utilitarian? Investigating user dilemma of hedonic-utilitarian choice", International Journal of Human-Computer Studies, Vol. 108, pp. 50-61.

Kivetz, R. and Zheng, Y.H. (2017), "The effects of promotions on hedonic versus utilitarian purchases", Journal of Consumer Psychology, Vol. 27 No. 1, pp. 59-68.

Lam, S.K., Ahearne, M. and Schillewaert, N. (2012), "A multinational examination of the symbolicinstrumental framework of consumer-brand identification", Journal of International Business Studies, Vol. 43 No. 3, pp. 306-331.

Lee, J. and Lee, J.N. (2015), "How purchase intention consummates purchase behaviour: the stochastic nature of product valuation in electronic commerce", Behaviour \& Information Technology, Vol. 34 No. 1, pp. 57-68.

Li, G.X., Li, G.F. and Kambele, Z. (2012), "Luxury fashion brand consumers in China: Perceived value, fashion lifestyle, and willingness to pay", Journal of Business Research, Vol. 65 No. 10, pp. 1516-1522.

Lin, J.S. and Sung, Y.J. (2014), "Nothing Can Tear Us Apart: The Effect of Brand Identity Fusion in Consumer-Brand Relationships", Psychology \& Marketing, Vol. 31 No. 1, pp. 54-69.

Low, G.S. and Lamb, C.W. (2000), "The measurement and dimensionality of brand associations", Journal of Product \& Brand Management, Vol. 9 No. 6, pp. 350-370.

Milliken, F.J. (1987), "Three Types of Perceived Uncertainty About the Environment: State, Effect, and Response Uncertainty", Academy of Management Review, Vol. 12 No. 1, pp. 133-143.

Miyazaki, A.D., Grewal, D. and Goodstein, R.C. (2005), "The Effect of Multiple Extrinsic Cues on Quality Perceptions: A Matter of Consistency", Journal of Consumer Research, Vol. 32 No. 1, 
pp. 146-153.

Moffitt, R.L., Neumann, D.L. and Williamson, S.P. (2018), "Comparing the efficacy of a brief selfesteem and self-compassion intervention for state body dissatisfaction and self-improvement motivation", Body Image, Vol. 27, pp. 67-76.

Moreau, C.P. and Herd, K.B. (2010), "To Each His Own? How Comparisons with Others Influence Consumers' Evaluations of Their Self-Designed Products", Journal of Consumer Research, Vol. 36 No. 5, pp. 806-819.

Muehlbacher, S., Hartl, B. and Kirchler, E. (2017), "Mental Accounting and Tax Compliance: Experimental Evidence for the Effect of Mental Segregation of Tax Due and Revenue on Compliance", Public Finance Review, Vol. 45 No. 1, pp. 118-139.

Mundel, J., Huddleston, P., Behe, B., Sage, L. and Latona, C. (2018), "An eye tracking study of minimally branded products: hedonism and branding as predictors of purchase intentions", Journal of Product and Brand Management, Vol. 27 No. 2, pp. 146-157.

Nishikawa, H., Schreier, M., Fuchs, C. and Ogawa, S. (2017), "The Value of Marketing Crowdsourced New Products as Such: Evidence from Two Randomized Field Experiments", Journal of Marketing Research, Vol. 54 No. 4, pp. 525-539.

Paharia, N. and Swaminathan, V. (2019), "Who Is Wary of User Design? The Role of Power-Distance Beliefs in Preference for User-Designed Products", Journal of Marketing, Vol. 83 No. 3, pp. 91 107.

Pavlou, P.A., Liang, H.G. and Xue, Y.J. (2007), "Understanding and mitigating uncertainty in online exchange relationships: A principal-agent perspective", Mis Quarterly, Vol. 31 No. 1, pp. 105136.

Podsakoff, P.M., MacKenzie, S.B., Lee, J.-Y. and Podsakoff, N.P. (2003), "Common method biases in behavioral research: a critical review of the literature and recommended remedies", The Journal of applied psychology, Vol. 88 No. 5, pp. 879-903.

Podsakoff, P.M. and Organ, D.W. (1986), "Self-Reports in Organizational Research: Problems and Prospects", Journal of Management, Vol. 12 No. 4, pp. 531-544.

Poetz, M.K. and Schreier, M. (2012), "The Value of Crowdsourcing: Can Users Really Compete with Professionals in Generating New Product Ideas?", Journal of Product Innovation Management, Vol. 29 No. 2, pp. 245-256. 
Prelec, D. and Loewenstein, G. (1998), "The Red and the Black: Mental Accounting of Savings and Debt", Marketing Science, Vol. 17 No. 1, pp. 4-28.

Roberts, D., Hughes, M. and Kertbo, K. (2014), "Exploring consumers' motivations to engage in innovation through co-creation activities", European Journal of Marketing, Vol. 48 No. 1-2, pp. 147-169.

Schreier, M., Fuchs, C. and Dahl, D.W. (2012), "The Innovation Effect of User Design: Exploring Consumers' Innovation Perceptions of Firms Selling Products Designed by Users", Journal of Marketing, Vol. 76 No. 5, pp. 18-32.

Sedikides, C. (1999), "A multiplicity of motives: The case of self-improvement", Psychological Inquiry, Vol. 10 No. 1, pp. 64-65.

Sheng Goh, Y., Chattaraman, V. and Forsythe, S. (2013), "Brand and category design consistency in brand extensions", Journal of Product \& Brand Management, Vol. 22 No. 4, pp. 272-285.

Simester, P.D. (2001), "Always Leave Home Without It: A Further Investigation of the Credit-Card Effect on Willingness to Pay", Marketing Letters, Vol. 12 No. 1, pp. 5-12.

Smith, D.C. and Park, W. (1992), "The effects of brand extensions on market share and advertising efficiency", Journal of Marketing Research, Vol. 29 No. 3, pp. 296-313.

Song, X.B., Jung, J.Y. and Zhang, Y.L. (2021), "Consumers' Preference for User-Designed Versus Designer-Designed Products: The Moderating Role of Power Distance Belief", Journal of Marketing Research, Vol. 58 No. 1, pp. 163-181.

Soster, R.L., Monga, A. and Bearden, W.O. (2010), "Tracking Costs of Time and Money: How Accounting Periods Affect Mental Accounting", Journal of Consumer Research, Vol. 37 No. 4, pp. 712-721.

Strahilevitz, M. and Myers, J.G. (1998), "Donations to Charity as Purchase Incentives: How Well They Work May Depend on What You Are Trying to Sell", Journal of Consumer Research, Vol. 24 No. 4, pp. 434-446.

Thaler, R.H. (2008), "Mental accounting and consumer choice", Marketing Science, Vol. 27 No. 1, pp. 15-25.

Troye, S.V. and Supphellen, M. (2012), "Consumer Participation in Coproduction: "I Made It Myself" Effects on Consumers' Sensory Perceptions and Evaluations of Outcome and Input Product", Journal of Marketing, Vol. 76 No. 2, pp. 33-46. 
von Hippel, E. (2005), Democratizing Innovation, MIT Press, Massachusetts.

Weathers, D., Sharma, S. and Wood, S.L. (2007), "Effects of online communication practices on consumer perceptions of performance uncertainty for search and experience goods", Journal of Retailing, Vol. 83 No. 4, pp. 393-401.

Williams, L.J., Edwards, J.R. and Vandenberg, R.J. (2003), "Recent Advances in Causal Modeling Methods for Organizational and Management Research", Journal of Management, Vol. 29 No. 6, pp. 903-936.

Young, D.L., Goodie, A.S., Hall, D.B. and Wu, E. (2012), "Decision making under time pressure, modeled in a prospect theory framework", Organizational Behavior and Human Decision Processes, Vol. 118 No. 2, pp. 179-188.

Zhang, C.Y. and Sussman, A.B. (2018), The Role of Mental Accounting in Household Spending and Investing Decisions, John Wiley \& Sons Inc, New Jersey.

Zhang, M., Qin, F., Wang, G.A. and Luo, C. (2020), "The impact of live video streaming on online purchase intention", Service Industries Journal, Vol. 40 No. 9-10, pp. 656-681. 
Table 1. A summary of the effects of user design

\begin{tabular}{|c|c|c|c|c|c|}
\hline Authors & Independent variables & Mediator variables & Dependent variables & Moderator variables & $\begin{array}{l}\text { Research } \\
\text { object }\end{array}$ \\
\hline Franke et al. (2009) & $\begin{array}{l}\text { preference insight, ability to } \\
\text { express preference, product } \\
\text { involvement }\end{array}$ & & $\begin{array}{l}\text { benefit derived from } \\
\text { customization }\end{array}$ & & $\begin{array}{l}\text { participating } \\
\text { users }\end{array}$ \\
\hline Franke et al. (2010) & $\begin{array}{l}\text { design product with a mass } \\
\text { customization toolkit }\end{array}$ & $\begin{array}{l}\text { feeling of } \\
\text { accomplishment }\end{array}$ & subjective value & $\begin{array}{l}\text { subjective preference fit of the product, } \\
\text { subjective contribution enabled by the } \\
\text { mass customization toolkit }\end{array}$ & $\begin{array}{l}\text { participating } \\
\text { users }\end{array}$ \\
\hline $\begin{array}{l}\text { Franke and Schreier } \\
(2010)\end{array}$ & $\begin{array}{l}\text { perceived process effort, } \\
\text { perceived process enjoyment }\end{array}$ & & $\begin{array}{l}\text { value the customer } \\
\text { attributes to self- } \\
\text { designed product }\end{array}$ & preference fit & $\begin{array}{l}\text { participating } \\
\text { users }\end{array}$ \\
\hline Fuchs et al. (2010) & $\begin{array}{l}\text { empowered customer, } \\
\text { nonempowered customers }\end{array}$ & $\begin{array}{l}\text { psychological } \\
\text { ownership }\end{array}$ & product demand & & $\begin{array}{l}\text { participating } \\
\text { users }\end{array}$ \\
\hline Addis et al. (2021) & fantastical thinking & $\begin{array}{l}\text { perceived ease, } \\
\text { enjoyment }\end{array}$ & $\begin{array}{l}\text { attitude, purchase } \\
\text { intention, satisfaction }\end{array}$ & & $\begin{array}{l}\text { participating } \\
\text { users }\end{array}$ \\
\hline Schreier et al. (2012) & $\begin{array}{l}\text { common design by users (vs. } \\
\text { company professionals) }\end{array}$ & $\begin{array}{l}\text { perceived innovation } \\
\text { ability }\end{array}$ & purchase intention & $\begin{array}{l}\text { consumers' general familiarity with user } \\
\text { innovation; complexity of underlying } \\
\text { product category }\end{array}$ & customers \\
\hline Fuchs et al. (2013) & $\begin{array}{l}\text { source of design (user- } \\
\text { designer vs. company } \\
\text { designer ) }\end{array}$ & $\begin{array}{l}\text { design quality } \\
\text { perceptions, agentic } \\
\text { feelings }\end{array}$ & product demand & $\begin{array}{l}\text { strategies to increase social distance in } \\
\text { user design, status relevance of product } \\
\text { category }\end{array}$ & customers \\
\hline Dahl et al. (2015) & $\begin{array}{l}\text { feeling of vicarious } \\
\text { empowerment }\end{array}$ & $\begin{array}{l}\text { identification with } \\
\text { the firm }\end{array}$ & $\begin{array}{l}\text { preference for } \\
\text { products }\end{array}$ & $\begin{array}{l}\text { perceived similarity to participating } \\
\text { users, participation openness of the firm }\end{array}$ & customers \\
\hline $\begin{array}{l}\text { Nishikawa et al. } \\
\text { (2017) }\end{array}$ & design source & $\begin{array}{l}\text { perceived product } \\
\text { quality }\end{array}$ & product preference & & customers \\
\hline $\begin{array}{l}\text { Paharia and } \\
\text { Swaminathan (2019) }\end{array}$ & $\begin{array}{l}\text { user design vs. company } \\
\text { design }\end{array}$ & $\begin{array}{l}\text { empowerment, } \\
\text { quality perceptions }\end{array}$ & brand preference & power-distance beliefs & customers \\
\hline
\end{tabular}


Table 2. Measurement scales (Study 1)

\begin{tabular}{|c|c|c|}
\hline Construct & Item & Source \\
\hline $\begin{array}{l}\text { Perceived self- } \\
\text { improvement }\end{array}$ & $\begin{array}{l}\text { Compared with T-shirt of Brand B, T-shirt of Brand A } \\
\text { can help me improve. } \\
\text { Compared with T-shirt of Brand B, T-shirt of Brand A } \\
\text { can help me become better. } \\
\text { Compared with T-shirt of Brand B, T-shirt of Brand A } \\
\text { can make me feel better self-image. } \\
\text { Compared with T-shirt of Brand B, T-shirt of Brand A } \\
\text { can help me enhance my performance. }\end{array}$ & $\begin{array}{l}\text { Allard and White } \\
\text { (2015) }\end{array}$ \\
\hline $\begin{array}{l}\text { Perceived } \\
\text { uncertainty }\end{array}$ & $\begin{array}{l}\text { How sure are you about the overall quality level of T- } \\
\text { shirt of Brand A? } \\
\text { It is difficult to judge the quality level and design level } \\
\text { of T-shirt of Brand A. } \\
\text { It is difficult to assess whether T-shirt of Brand A meets } \\
\text { your needs. } \\
\text { It is difficult to predict how others evaluate T-shirt of } \\
\text { Brand A. }\end{array}$ & $\begin{array}{l}\text { Weathers et al. } \\
\qquad \text { (2007) }\end{array}$ \\
\hline Purchase intention & $\begin{array}{l}\text { I will probably buy a T-shirt of Brand A. } \\
\text { I will recommend the T-shirt of Brand A to others. } \\
\text { I am very willing to use a T-shirt of Brand A. }\end{array}$ & Gilly et al. (1998) \\
\hline
\end{tabular}

Note: Take T-shirt of Brand A as an example.

Table 3. Reliability and convergent validity measurements (Study 1)

\begin{tabular}{lccccc}
\hline \multicolumn{1}{c}{ Construct } & Item & $\begin{array}{c}\text { Factor } \\
\text { loading }\end{array}$ & AVE & $\begin{array}{c}\text { Composite } \\
\text { reliability }\end{array}$ & Cronbach's $\alpha$ \\
\hline Perceived self- & $P S I 1$ & 0.717 & & & \\
improvement & $P S I 2$ & 0.747 & 0.625 & 0.869 & 0.868 \\
$($ PSI) & $P S I 3$ & 0.873 & & & \\
& $P S I 4$ & 0.816 & & & \\
Perceived & $P U 1$ & 0.848 & & & \\
uncertainty & $P U 2$ & 0.891 & 0.741 & & \\
(PU) & $P U 3$ & 0.874 & & & \\
& $P U 4$ & 0.828 & & & \\
Purchase & $P I 1$ & 0.794 & & & \\
intention (PI) & $P I 2$ & 0.666 & 0.563 & & \\
& $P I 3$ & 0.784 & & & \\
\hline
\end{tabular}


Table 4. Correlation matrix (Study 1)

\begin{tabular}{lccc}
\hline Variables & 1 & 2 & 3 \\
\hline 1. $P I$ & $(0.750)$ & & \\
2. $P U$ & -0.293 & $(0.861)$ & \\
3. $P S I$ & 0.216 & 0.385 & $(0.791)$ \\
\hline
\end{tabular}

Note: Correlations on the diagonal are the square root of the AVE value

Table 5. ANOVA results of design sources $\times$ designer information (I)

\begin{tabular}{lccccc}
\hline \multicolumn{1}{c}{ Source } & $\begin{array}{c}\text { Type III Sum of } \\
\text { Squares }\end{array}$ & df & $\begin{array}{c}\text { Mean } \\
\text { Square }\end{array}$ & F & Sig. \\
\hline Design sources & 52.041 & 1 & 52.041 & 80.606 & 0.000 \\
$\begin{array}{l}\text { Designer information } \\
\begin{array}{l}\text { Design sources } \times \text { Designer } \\
\text { information }\end{array}\end{array}$ & 7.988 & 1 & 7.988 & 12.372 & 0.000 \\
\hline
\end{tabular}

Table 6. ANOVA results of design source $\times$ designer information (II)

\begin{tabular}{lccccc}
\hline \multicolumn{1}{c}{ Source } & $\begin{array}{c}\text { Type III Sum of } \\
\text { Squares }\end{array}$ & df & $\begin{array}{c}\text { Mean } \\
\text { Square }\end{array}$ & F & Sig. \\
\hline Design sources & 6.910 & 1 & 6.910 & 7.837 & 0.000 \\
Designer information & 0.207 & 1 & 0.207 & 0.234 & 0.000 \\
$\begin{array}{l}\text { Design sources } \times \text { Designer } \\
\text { information }\end{array}$ & 8.907 & 1 & 8.907 & 10.102 & 0.013 \\
\hline
\end{tabular}

Table 7. Demographic information

\begin{tabular}{cccc}
\hline Demographic variables & Category & Frequency & Percentage \\
\hline \multirow{2}{*}{ Gender } & Female & 155 & $50.3 \%$ \\
& Male & 157 & $49.7 \%$ \\
\multirow{2}{*}{ Age } & $18-25$ & 105 & $33.7 \%$ \\
& $26-35$ & 115 & $36.9 \%$ \\
\multirow{3}{*}{ Occupation } & $36-45$ & 87 & $27.9 \%$ \\
& 46 or over & 5 & $1.6 \%$ \\
& Student & 116 & $37.2 \%$ \\
Education level & Employee & 98 & $31.4 \%$ \\
& Others & 98 & $31.4 \%$ \\
& Below high school & 78 & $25.0 \%$ \\
& High school & 81 & $26.0 \%$ \\
& Undergraduate & 74 & $23.7 \%$
\end{tabular}




\begin{tabular}{cccc} 
& $1-5$ & 105 & $33.65 \%$ \\
Online shopping frequency & $6-10$ & 79 & $25.32 \%$ \\
(times per month) & $11-15$ & 96 & $30.77 \%$ \\
& More than 15 & 32 & $10.26 \%$ \\
\hline
\end{tabular}

Table 8. Reliability and convergent validity measurements (Study 2)

\begin{tabular}{|c|c|c|c|c|c|}
\hline Construct & Item & $\begin{array}{l}\text { Factor } \\
\text { loading }\end{array}$ & AVE & $\begin{array}{l}\text { Composite } \\
\text { reliability }\end{array}$ & Cronbach's $\alpha$ \\
\hline \multirow{4}{*}{$\begin{array}{l}\text { Perceived self- } \\
\text { improvement (PSI) }\end{array}$} & PSII & 0.942 & \multirow{4}{*}{0.839} & \multirow{4}{*}{0.954} & \multirow{4}{*}{0.954} \\
\hline & PSI2 & 0.889 & & & \\
\hline & PSI3 & 0.940 & & & \\
\hline & PSI4 & 0.892 & & & \\
\hline \multirow{4}{*}{$\begin{array}{l}\text { Perceived } \\
\text { uncertainty }(P U)\end{array}$} & PU1 & 0.919 & \multirow{4}{*}{0.832} & \multirow{4}{*}{0.952} & \multirow{4}{*}{0.952} \\
\hline & PU2 & 0.902 & & & \\
\hline & PU3 & 0.916 & & & \\
\hline & PU4 & 0.912 & & & \\
\hline \multirow{3}{*}{$\begin{array}{l}\text { Purchase intention } \\
\text { (PI) }\end{array}$} & $P I 1$ & 0.874 & \multirow{3}{*}{0.776} & \multirow{3}{*}{0.912} & \multirow{3}{*}{0.912} \\
\hline & $P I 2$ & 0.890 & & & \\
\hline & $P I 3$ & 0.878 & & & \\
\hline
\end{tabular}

Table 9. Correlation matrix (Study 2)

\begin{tabular}{lccc}
\hline Variables & 1 & 2 & 3 \\
\hline 1. PI & $(0.916)$ & & \\
2. $P U$ & -0.356 & $(0.912)$ & \\
3. PSI & 0.348 & 0.438 & $(0.916)$ \\
\hline
\end{tabular}

Note: Correlations on the diagonal are the square root of the AVE value

Table 10. Testing the moderating effect of brand strength

\begin{tabular}{|c|c|c|c|c|c|c|c|c|c|}
\hline \multirow{2}{*}{ Predictors } & & \multicolumn{4}{|c|}{ Model 1 (perceived self-improvement) } & \multicolumn{4}{|c|}{ Model 2 (perceived uncertainty) } \\
\hline & & $\beta$ & se & $t$ & $p$ & $\beta$ & se & $t$ & $p$ \\
\hline Design sources & & 1.914 & 0.113 & 16.883 & 0.000 & 0.630 & 0.155 & 4.057 & 0.001 \\
\hline Brand strength & & 0.344 & 0.113 & 11.857 & 0.000 & 0.115 & 0.155 & 0.743 & 0.458 \\
\hline $\begin{array}{l}\text { Design sources } \\
\text { Brand strength }\end{array}$ & $\times$ & -1.852 & 0.160 & -11.552 & 0.000 & -0.238 & 0.220 & -1.084 & 0.279 \\
\hline $\begin{array}{l}R^{2} \\
F\end{array}$ & & \multicolumn{4}{|c|}{0.504} & \multicolumn{4}{|c|}{0.069} \\
\hline
\end{tabular}

Note: ${ }^{* * *} p<0.001$. 


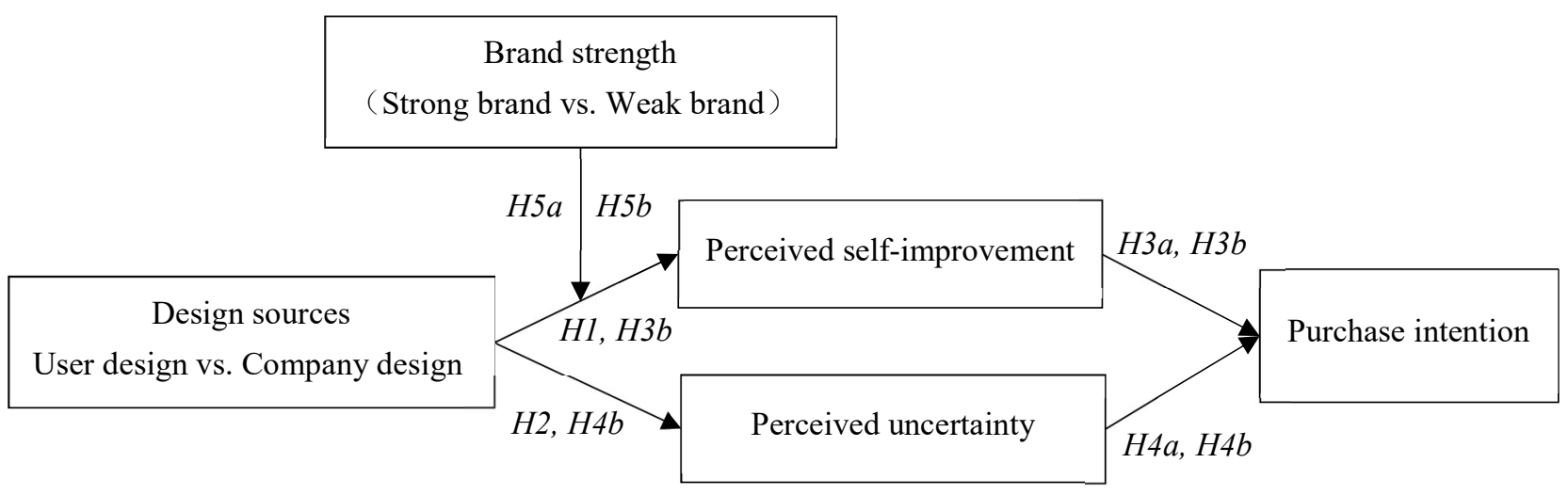

Figure 1. Research hypotheses

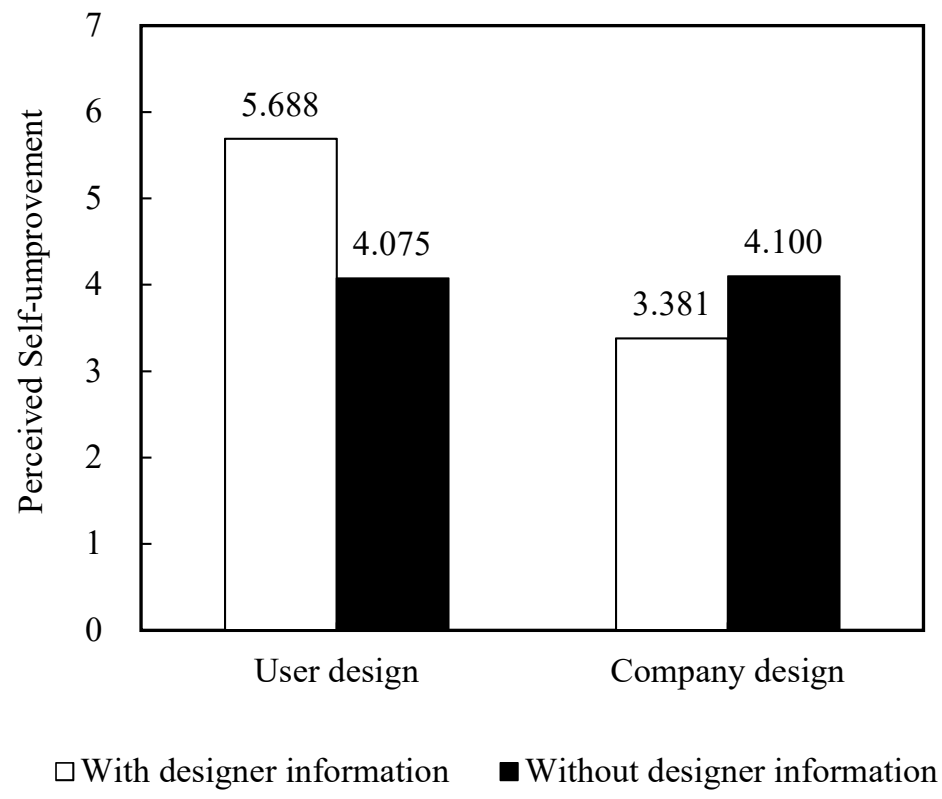

Figure 2. The effect of design sources and designer information on perceived selfimprovement 


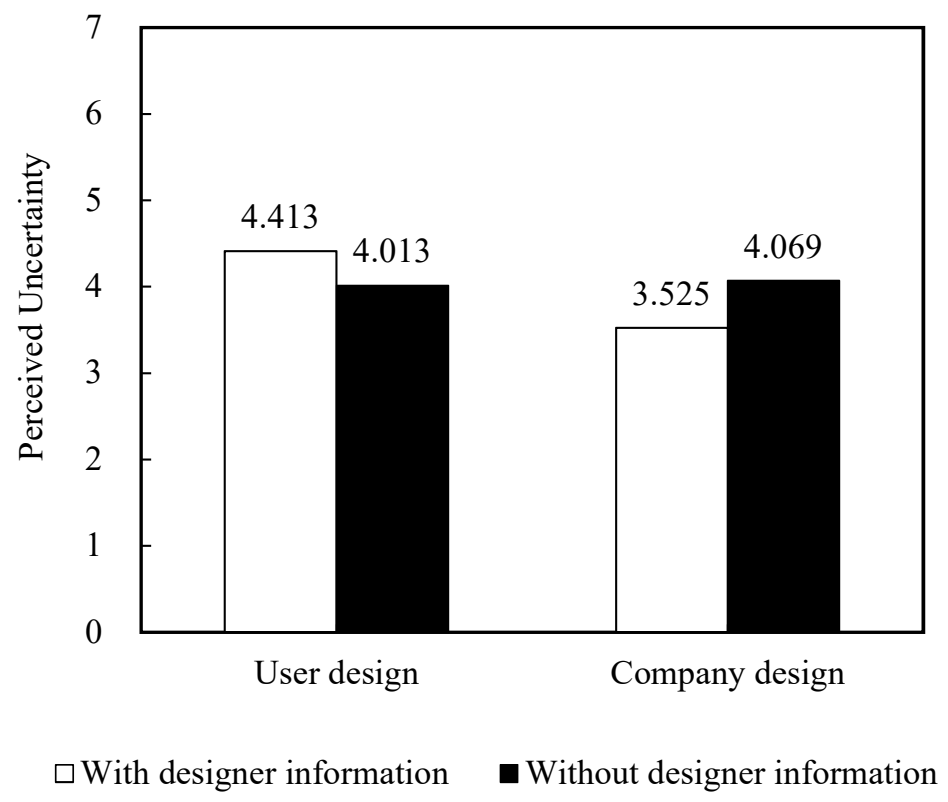

Figure 3. The effect of design sources and designer information on perceived uncertainty

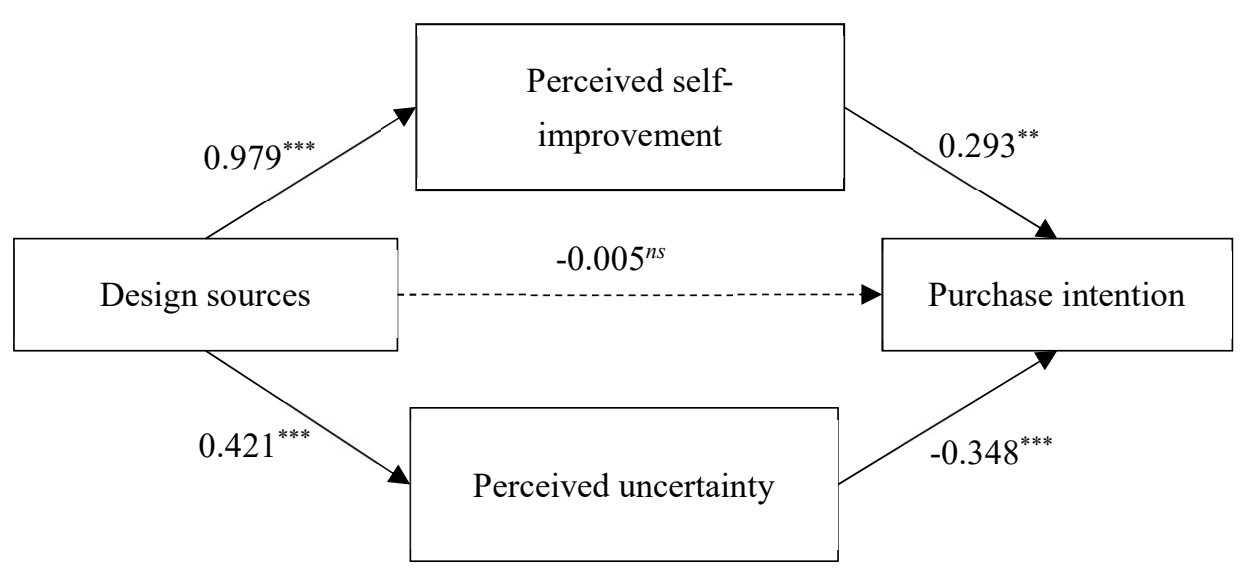

Note: ${ }^{* *} p<0.01 ;{ }^{* * *} p<0.001 ;{ }^{n s}$ Not significant.

Figure 4. Mediation analysis 


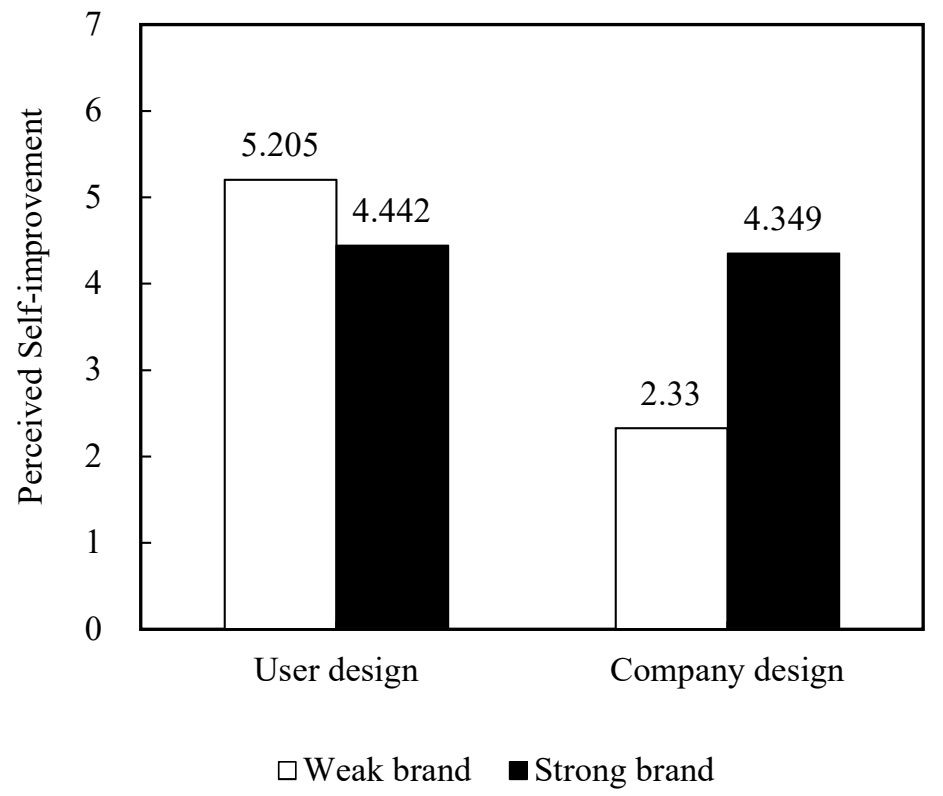

Figure 5. The effect of design sources and designer information on perceived selfimprovement 


\section{Appendix}

\section{Study 1}

\subsection{The stimulus}

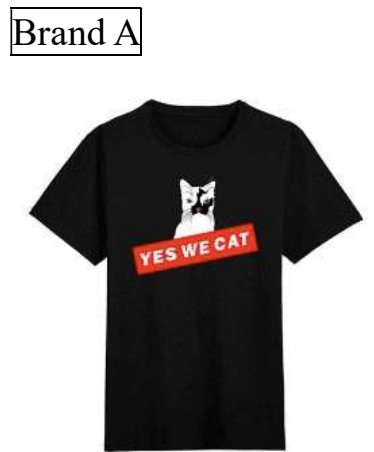

Brand B

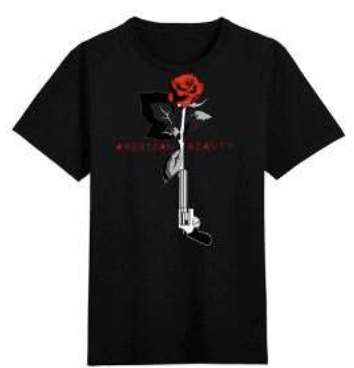

Figure A1. Description of T-shirts

\subsection{The text about the information of designer}

These two brands adopt different design approaches. Among them, the T-shirt of brand A is designed by professional designers of the company, while the T-shirt of Brand $\mathrm{B}$ is designed by a customer of the brand community.

\subsection{Questionnaire items}

(1) The group of company design

Table A1. Questionnaire items of the group of company design (Study 1)

\begin{tabular}{ll}
\hline 1 & what's your name? \\
2 & what's your age? \\
3 & What's your gender? \\
\hline
\end{tabular}

Please answer the following questions according to your observation of the two Tshirts and your real feelings.

4

Compared with T-shirt of Brand B, T-shirt of Brand A can help me improve.

$1=$ strongly disagree, $7=$ strongly agree

Compared with T-shirt of Brand B, T-shirt of Brand A can help me $1=$ strongly disagree, $7=$ become better. strongly agree $1=$ strongly me feel better self-image. 
Compared with T-shirt of Brand B, T-shirt of Brand A can help me enhance my performance.

How sure are you about the overall quality level of T-shirt of Brand A?

9

It is difficult to judge the quality level and design level of T-shirt of Brand A.

10

It is difficult to assess whether T-shirt of Brand A meets your needs.

2 I will probably buy a $\mathrm{T}$-shirt of Brand $\mathrm{A}$

13 I will recommend the T-shirt of Brand A to others.

14 I am very willing to use a T-shirt of Brand A.

$1=$ strongly

disagree, $7=$ strongly agree $1=$ strongly disagree, $7=$ strongly agree $1=$ strongly disagree, $7=$ strongly agree $1=$ strongly disagree, $7=$ strongly agree $1=$ strongly

11 It is difficult to predict how others evaluate T-shirt of Brand A. disagree, $7=$ strongly agree $1=$ strongly disagree, $7=$ strongly agree $1=$ strongly disagree, $7=$ strongly agree $1=$ strongly disagree, $7=$ strongly agree

(2) The group of user design

Table A2. Questionnaire items of the group of user design (Study 1)

\begin{tabular}{lll}
\hline 1 & what's your name? & \\
2 & what's your age? \\
3 & What's your gender? & \\
\hline & $\begin{array}{l}\text { Please answer the following questions according to your observation of the two T- } \\
\text { shirts and your real feelings. }\end{array}$ \\
\hline $\begin{array}{l}\text { Compared with T-shirt of Brand A, T-shirt of Brand B can help me } \\
\text { improve. }\end{array}$ & $\begin{array}{l}1=\text { strongly } \\
\text { disagree, } 7= \\
\text { strongly agree } \\
1=\text { strongly } \\
\text { disagree, } 7= \\
\text { strongly agree } \\
1=\text { strongly } \\
\text { disagree, } 7= \\
\text { strongly agree }\end{array}$ \\
\hline
\end{tabular}


7

Compared with T-shirt of Brand A, T-shirt of Brand B can help me enhance my performance.

8

How sure are you about the overall quality level of T-shirt of Brand $\mathrm{B}$ ?

It is difficult to judge the quality level and design level of T-shirt of Brand B.

10

It is difficult to assess whether T-shirt of Brand B meets your needs.

11 It is difficult to predict how others evaluate T-shirt of Brand B.

12 I will probably buy a T-shirt of Brand B.

13 I will recommend the T-shirt of Brand B to others.

14 I am very willing to use a T-shirt of Brand B.
1 = strongly

disagree, $7=$ strongly agree 1 =very uncertain, $7=$ very sure 1 = strongly disagree, $7=$ strongly agree $1=$ strongly disagree, 7 = strongly agree $1=$ strongly disagree, $7=$ strongly agree 1 = strongly disagree, $7=$ strongly agree $1=$ strongly disagree, $7=$ strongly agree $1=$ strongly disagree, $7=$ strongly agree

\subsection{The results of normality test}

Table A3. Descriptive Statistics (Study 1)

\begin{tabular}{|c|c|c|c|c|c|c|c|c|c|}
\hline & \multirow{2}{*}{$\begin{array}{c}\mathrm{N} \\
\text { Statisti } \\
\mathrm{c}\end{array}$} & \multirow{2}{*}{$\begin{array}{c}\begin{array}{c}\text { Minimu } \\
\mathrm{m}\end{array} \\
\text { Statistic }\end{array}$} & \multirow{2}{*}{$\begin{array}{c}\text { Maximu } \\
\mathrm{m}\end{array}$} & \multirow{2}{*}{$\begin{array}{l}\text { Mean } \\
\text { Statisti } \\
\text { c }\end{array}$} & \multirow{2}{*}{ 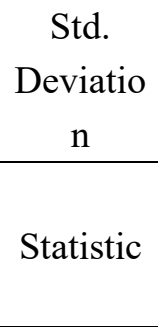 } & \multicolumn{2}{|c|}{ Skewness } & \multicolumn{2}{|c|}{ Kurtosis } \\
\hline & & & & & & $\begin{array}{l}\text { Statisti } \\
\text { c }\end{array}$ & $\begin{array}{l}\text { Std. } \\
\text { Erro } \\
\text { r }\end{array}$ & $\begin{array}{l}\text { Statisti } \\
\text { c }\end{array}$ & $\begin{array}{c}\text { Std. } \\
\text { Erro } \\
\text { r }\end{array}$ \\
\hline $\begin{array}{l}\text { Perceived } \\
\text { self- } \\
\text { improveme } \\
\text { nt }\end{array}$ & $\begin{array}{c}160.00 \\
0\end{array}$ & 1.500 & 7.000 & 4.311 & 1.163 & 0.189 & $\begin{array}{c}0.19 \\
2\end{array}$ & -0.650 & $\begin{array}{c}0.38 \\
1\end{array}$ \\
\hline $\begin{array}{l}\text { Perceived } \\
\text { uncertainty }\end{array}$ & $\begin{array}{c}160.00 \\
0\end{array}$ & 1.500 & 6.750 & 4.005 & 0.983 & 0.107 & $\begin{array}{c}0.19 \\
2\end{array}$ & -0.123 & $\begin{array}{c}0.38 \\
1\end{array}$ \\
\hline $\begin{array}{l}\text { Purchase } \\
\text { intention }\end{array}$ & $\begin{array}{c}160.00 \\
0\end{array}$ & 1.000 & 6.000 & 3.263 & 0.977 & 0.145 & $\begin{array}{c}0.19 \\
2\end{array}$ & -0.238 & $\begin{array}{c}0.38 \\
1\end{array}$ \\
\hline
\end{tabular}




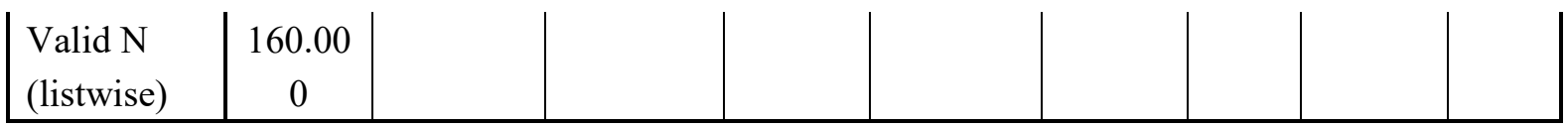

\section{Study 2}

2.1 The stimulus

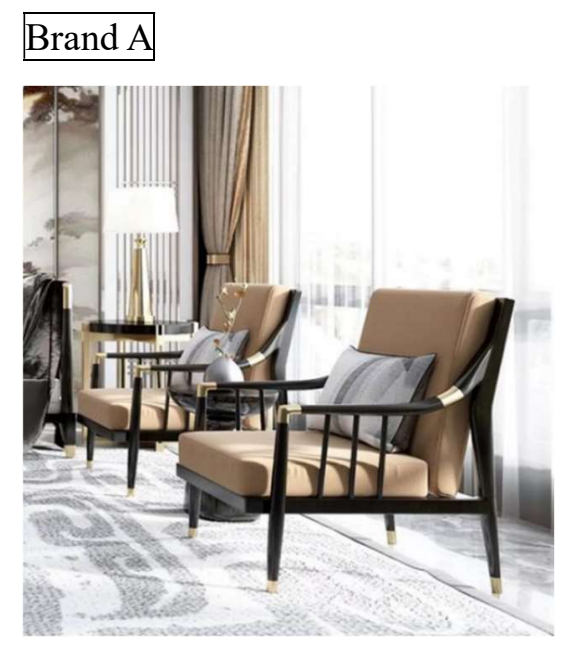

Brand B

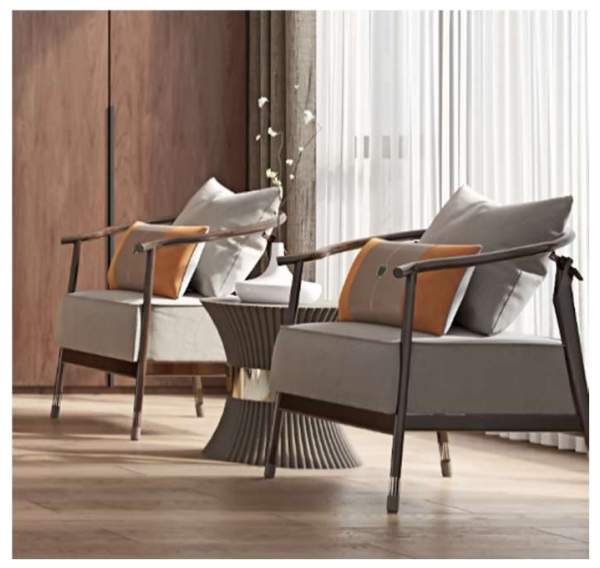

Figure A2. Description of Chairs 


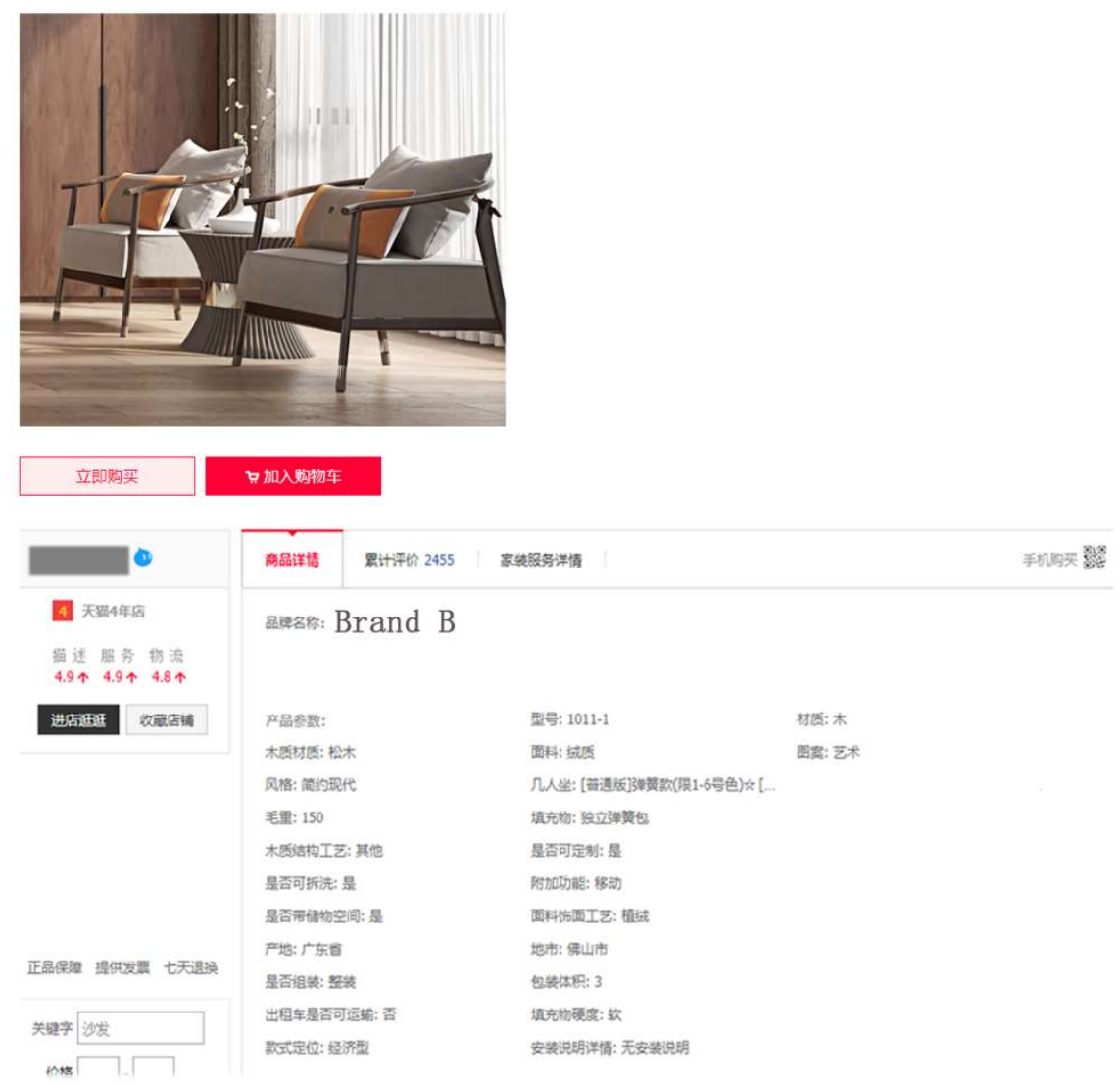

Figure A3. The sample of web page of online store

\subsection{The measurement scales}

(1) The group of company design

Table A4. Questionnaire items of the group of company design (Study 1)

1 what's your name?

2 what's your age?

3 What's your gender?

4 What is your job?

5 What is your education level?

Please answer the following questions according to your observation of the two Chairs and your real feelings.

\begin{tabular}{lll}
\hline & Please rate the Brand A according to your judgment. & $\begin{array}{l}1=\text { Ordinary } \\
\text { brand, 7=Leading } \\
\text { brand } \\
1=\text { weak brand, } \\
7 \text { Please rate the Brand A according to your judgment again. }\end{array}$ \\
\hline
\end{tabular}


Compared with chair of Brand B, chair of Brand A can make me feel better self-image.

11

Compared with chair of Brand B, chair of Brand A can help me enhance my performance.

12

How sure are you about the overall quality level of chair of Brand A?

It is difficult to judge the quality level and design level of chair of Brand A.

14 It is difficult to assess whether chair of Brand A meets your needs.

15 It is difficult to predict how others evaluate chair of Brand A.

16 I will probably buy a chair of Brand A.

17 I will recommend the chair of Brand A to others.

18 I am very willing to use a chair of Brand A.
$1=$ strongly

disagree, $7=$

strongly agree

1 = strongly

disagree, $7=$

strongly agree

1 = strongly

disagree, 7 =

strongly agree

1 = strongly

disagree, 7 =

strongly agree

1 =very

uncertain, $7=$

very sure

1 = strongly

disagree, 7 =

strongly agree

$1=$ strongly

disagree, 7 =

strongly agree

$1=$ strongly

disagree, 7 =

strongly agree

1 = strongly

disagree, $7=$

strongly agree

1 = strongly

disagree, $7=$

strongly agree

1 = strongly

disagree, $7=$

strongly agree

(2) The group of user design

Table A5. Questionnaire items of the group of company design (Study 2)

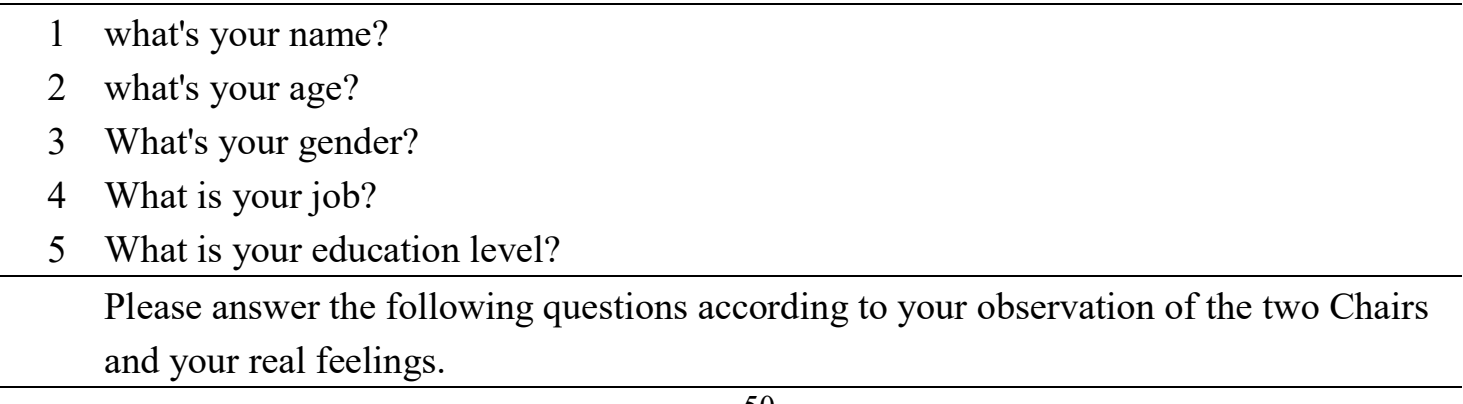


$1=$ Ordinary

6 Please rate the Brand B according to your judgment.

brand, 7=Leading

brand

7 Please rate the Brand B according to your judgment again.

1 = weak brand,

$7=$ strong brand

$1=$ strongly

Compared with chair of Brand A, chair of Brand B can help me improve.

disagree, $7=$ strongly agree

$1=$ strongly disagree, $7=$ strongly agree

$1=$ strongly disagree, $7=$ strongly agree $1=$ strongly disagree, $7=$ strongly agree 1 =very

12 B? Compared with chair of Brand A, chair of Brand B can help me enhance my performance.

uncertain, $7=$ very sure $1=$ strongly disagree, $7=$ strongly agree $1=$ strongly

14 It is difficult to assess whether chair of Brand B meets your needs. disagree, $7=$ strongly agree $1=$ strongly

15 It is difficult to predict how others evaluate chair of Brand B. disagree, $7=$ strongly agree $1=$ strongly

16 I will probably buy a chair of Brand B. disagree, $7=$ strongly agree $1=$ strongly

17 I will recommend the chair of Brand B to others. disagree, $7=$ strongly agree $1=$ strongly

18 I am very willing to use a chair of Brand B. disagree, $7=$ strongly agree

\subsection{The results of normality test}

Table A6. Descriptive Statistics (Study 2) 


\begin{tabular}{|l|c|c|c|c|c|c|c|c|c|}
\hline & $\mathrm{N}$ & $\begin{array}{c}\text { Minimu } \\
\mathrm{m}\end{array}$ & $\begin{array}{c}\text { Maximu } \\
\mathrm{m}\end{array}$ & Mean & $\begin{array}{c}\text { Std. } \\
\text { Deviatio } \\
\mathrm{n}\end{array}$ & \multicolumn{2}{|c|}{ Skewness } & \multicolumn{2}{|c|}{ Kurtosis } \\
\cline { 2 - 9 } & Statistic & Statistic & Statistic & $\begin{array}{c}\text { Statisti } \\
\mathrm{c}\end{array}$ & Statistic & $\begin{array}{c}\text { Statisti } \\
\mathrm{c}\end{array}$ & $\begin{array}{c}\text { Std. } \\
\text { Erro } \\
\mathrm{r}\end{array}$ & $\begin{array}{c}\text { Statisti } \\
\mathrm{c}\end{array}$ & $\begin{array}{c}\text { Std. } \\
\text { Erro } \\
\mathrm{r}\end{array}$ \\
\hline $\begin{array}{l}\text { Perceived } \\
\text { self- } \\
\text { improvem } \\
\text { ent } \\
\begin{array}{l}\text { Perceived } \\
\text { uncertaint } \\
\mathrm{y}\end{array}\end{array}$ & 312.000 & 1.667 & 7.000 & 4.153 & 1.071 & 0.151 & $\begin{array}{c}0.13 \\
8\end{array}$ & -0.510 & $\begin{array}{c}0.27 \\
5\end{array}$ \\
$\begin{array}{l}\text { Purchase } \\
\text { intention } \\
\begin{array}{l}\text { Valid N } \\
\text { (listwise) }\end{array}\end{array}$ & 312.000 & 1.000 & 7.000 & 4.082 & 1.502 & -0.229 & 0.13 & -0.962 & 0.27 \\
5
\end{tabular}

